\title{
2. DOWNHOLE VARIATIONS IN GRAIN SIZE AT HOLE 504B: IMPLICATIONS FOR RIFTING EPISODES AT MID-OCEAN RIDGES ${ }^{1}$
}

\author{
Susumu Umino
}

\begin{abstract}
The maximum grain sizes of plagioclase and magnetite in the groundmass of the sheeted dike complex drilled at Hole 504B have been measured. Downhole variations through a 440 -m-long section show a crude zig-zag pattern consisting of a gradual decrease or increase followed by an abrupt jump. The gradual decrease or increase in grain size extends over many lithologic units, and hence, does not reflect variations in grain size within a single dike. Such a zig-zag pattern is well explained by grain-size variations through multiple dikes. By using the observed inclination of sheeted dikes of $81^{\circ} \pm 2.5^{\circ}$, thickness of the multiple dikes varies from 0.7 to $8.5 \mathrm{~m}$ and averages to $4 \pm 1 \mathrm{~m}$. The average thickness of individual dikes forming multiple dikes is $0.8 \mathrm{~m}$. We expect such multiple dikes to be formed during rifting events beneath mid-oceanic spreading ridges. If the average expansion at rifting episodes is twice as wide as the average width of the multiple dike units, the full spreading rate of $7.2 \mathrm{~cm} / \mathrm{yr}$ of Cocos Ridge gives $112 \pm 33 \mathrm{yr}$ for a time interval of the rifting.

A simple one-dimensional conductive cooling model is applied to solidification of multiple dikes. Numerical simulations show that the grain-size variations observed through the drill hole are more consistent with a model where a new injection of a dike occurs periodically with a constant time interval rather than one where the next dike intrudes just after the solidification of the previous one. Grain-size variations within simple dikes from Iritono, Japan, and those for Makaopuhi lava lake, Hawaii, show that square root of crystallization time is linearly correlated with the logarithm of plagioclase size. By using an empirically derived relationship between these two variables, the variations of plagioclase size through Hole 504B are directly compared with the calculated times for crystallization. Each rifting episode at the Costa Rica Rift lasts for several years, and periodic injection of a new dike occurs into the center of a previously solidified multiple dike at time intervals varying from 1 to 12 months.
\end{abstract}

\section{INTRODUCTION}

The majority of Earth's magmas are produced through asthenospheric upwelling and partial melting processes beneath divergent plate boundaries, and hence, mid-ocean ridges are the loci of intense scientific research. Geophysical, structural, and petrological studies on mid-ocean spreading centers and ophiolites have revealed that most magmas solidify in the crust without erupting. At deeper levels in the crust, magmas solidify as cumulate layers, sheets, or pods, while at shallower levels, they form sheeted dike swarms. Thus, intrusion of dikes plays a fundamental role in crustal accretion at spreading centers. Recent progress in geomorphological studies on volcanic landforms and tectonic features suggests that volcanic processes similar to those at mid-ocean ridges also operate at Iceland; volcanic landforms comprise major volcanic edifices probably fed through long, continuous fissures, and smaller volcanic cones covering the former edifices (Kong et al., 1989; Smith and Cann, 1992). Historical and prehistorical records of earthquakes and land deformations, as well as volcanic eruptions in Iceland, suggest that such extensive lava shields are formed by large eruptions taking place at intervals of several hundred year, while central volcanoes are foci of magma intrusions at rifting episodes every $100-150 \mathrm{yr}$ (Sigurdsson and Sparks, 1978). Seismological and geodetic data on a recent rifting episode at Krafla, northern Iceland, show that plate accretion is accomplished by repeated dike intrusions from a local magma source through a narrow rift zone, followed by crustal movements during post-rifting stress relaxation (Tryggvason, 1984; Foulger et al., 1992). Rifting at mid-oceanic ridges is likely to occur in a way similar to that in Iceland. However, deep oceans exceeding 3000 $m$ prohibits direct observation of volcanic eruptions and shallow intrusive events at mid-oceanic spreading centers.

The previous Ocean Drilling Program (ODP) Legs 83 and 111 deepened Hole 504B through the lava/dike transition zone down to

\footnotetext{
${ }^{1}$ Erzinger, J., Becker, K., Dick, H.J.B., and Stokking, L.B. (Eds.), 1995. Proc. ODP, Sci. Results, 137/140: College Station, TX (Ocean Drilling Program).

${ }^{2}$ Institute of Geosciences, Shizuoka University, Ohya 836, Shizuoka 422, Japan.
}

the sheeted dikes (Adamson, 1985; Becker, Sakai, et al., 1988). ODP Leg 140 further deepened Hole 504B to $2000.4 \mathrm{mbsf}$ and cored 47.69 $\mathrm{m}$ of sheeted dikes in a section with a total length of $378.9 \mathrm{~m}$. Through these sections of the drill hole, dikes are found to be inclined northward to the ridge axis with inclinations steepening downhole (Shipboard Scientific Party, 1992). On the basis of grain-size variation in the sheeted dikes, I estimate time intervals and duration of dike intrusions, and discuss the 5.9-Ma rifting events at Costa Rica Rift.

\section{SHEETED DIKES IN HOLE 504B}

The first appearance of dikes in Hole 504B is at $846 \mathrm{mbsf}$, where a chilled contact against upper pillow lava is observed. The number of dikes increases below $960 \mathrm{mbsf}$ and the last pillow is recovered at 1055 mbsf. Below this point, all the rocks recovered are predominantly massive and are interpreted to be sheeted dikes (Adamson, 1985; Becker, Sakai, et al., 1988; Shipboard Scientific Party, 1992). The upper part of the dike section is composed of coarse-grained basalt or fine-grained diabase; however, the lower section drilled during Leg 140 is composed of fine- to coarse-grained diabase excluding the chilled margins. These dikes are also steeply inclined northward to the ridge axis of Costa Rica Rift. Intrusive contacts observed on Leg 83 dip $50^{\circ}-60^{\circ}$ from horizontal (Adamson, 1985), whereas Becker, Sakai, et al. (1988) estimated the average dike dip to be $68^{\circ}$, with a significant proportion of the dikes measuring $82^{\circ}$ based on paleomagnetic measurements. They inferred a tilting of the older dikes before the intrusion of the steeper dipping dikes. After expanding the recovered cores to fit the cored interval, widths of dikes drilled during Legs 83 and 111 are calculated, assuming that each lithologic unit forms a single dike (Fig. 1). Similar calculations are made on the sheeted dikes of Leg 140, using an average dip of $81.5^{\circ}$ on the basis of the recovered chilled contacts.

The most frequent dike width is less than $0.2 \mathrm{~m}$, which is far less than that of 0.4-0.6 m estimated by Becker, Sakai, et al. (1988). A small peak between 1.2 and $1.6 \mathrm{~m}$ is in the range of another peak frequency of the dike width of $1.2-1.8 \mathrm{~m}$ by the previous study. Because 


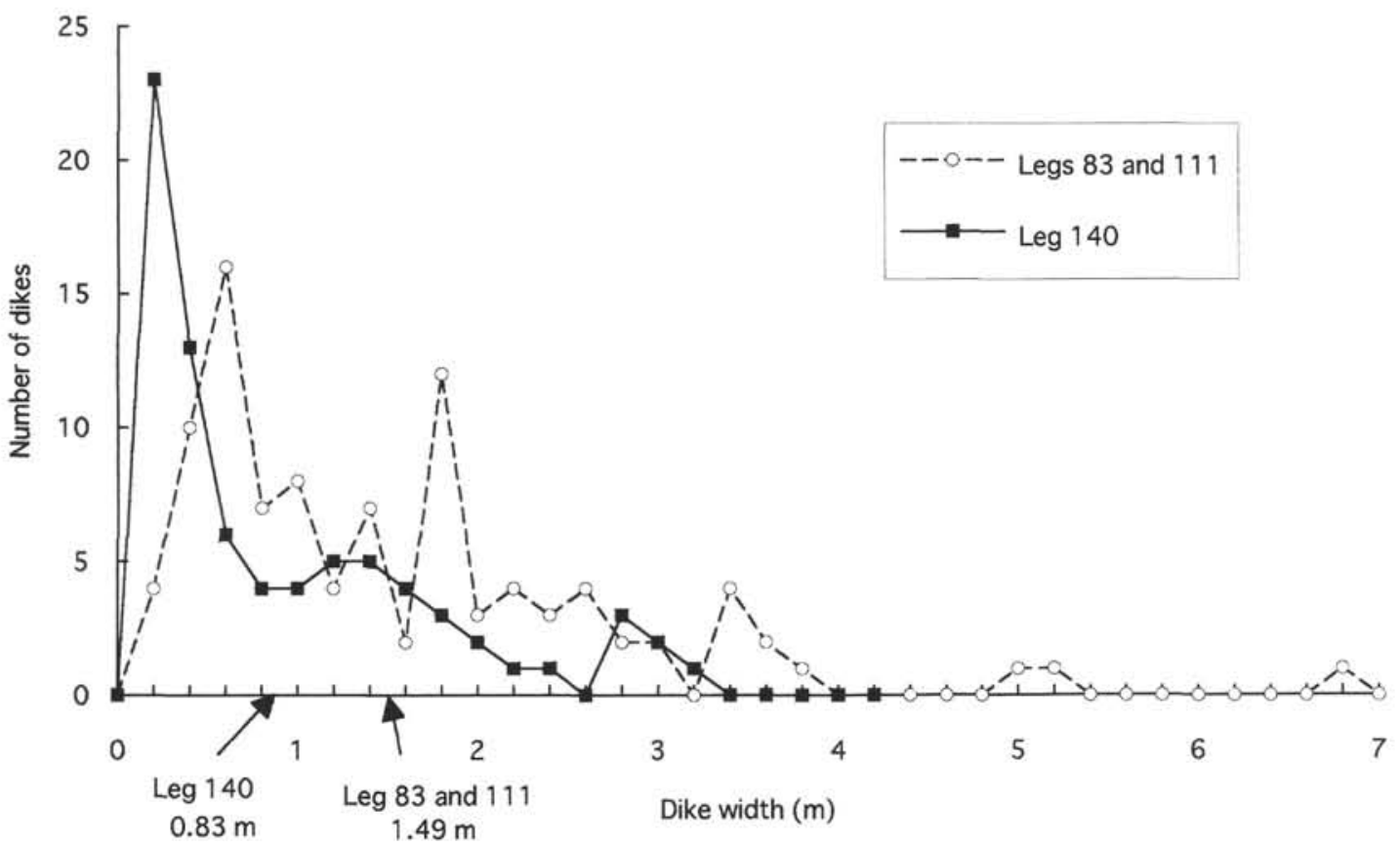

Figure 1. Frequency of dike widths drilled during Legs 83 and 111 (Becker, Sakai, et al., 1988) and Leg 140. The average dike width is $1.49 \mathrm{~m}$ for Legs 83 and 111 , whereas it is $0.83 \mathrm{~m}$ for Leg 140 .

unit boundaries are placed where an abrupt change in lithology is observed, some boundaries may separate a finer grained margin and a coarser grained core of the same dike. The frequency of smaller dikes may be overestimated to some extent.

\section{PETROGRAPHY}

Except for chilled margins of the dikes, all samples are mediumto coarse-grained diabase. Phenocrysts are of plagioclase, olivine, and augite, but some samples lack olivine or augite. $\mathrm{Cr}$-spinel is occasionally included in plagioclase phenocrysts and less commonly in olivine; it rarely occurs as discrete, large crystals in the groundmass.

Groundmass plagioclase is generally elongated and frequently acicular in shape. Some are skeletal and have hollow cores. Some plagioclases have euhedral, tabular cores rimmed with skeletal overgrowths, which probably began to crystallize as microphenocrysts. There are, thus, two or three stages of nucleation and growth of plagioclase crystals. Plagioclase without any apparent zonation under an optical microscope probably crystallized at the latest stage and are identified as a groundmass mineral. These crystals often broaden toward one end or both and sometimes are curved, subophitically enclosed in groundmass clinopyroxene. Secondary sulfide minerals also occur in the groundmass, but these have equant, euhedral shapes with clear outlines, and can be readily distinguished under transmitted light from magnetites which is generally decomposed to an aggregate of skeletal ilmenite and titanite.

All the analyzed samples have whole-rock compositions of normal mid-ocean-ridge basalts (N-MORBs) but are in the most depleted extremity in incompatible elements (Shipboard Scientific Party, 1992). They are moderately evolved and have limited ranges in $\mathrm{MgO}$ from 7.7 to $10.1 \mathrm{wt} \%$ and in $\mathrm{Mg} /(\mathrm{Mg}+\mathrm{Fe})$ ratio from 0.61 to 0.72 . Chemical variations within individual lithologic units exceed more than half of the spectrum of the chemical variations of the whole sections.

\section{DOWNHOLE GRAIN-SIZE VARIATION IN HOLE 504B}

The maximum grain size of plagioclase and magnetite in the groundmass was measured under a microscope as described in Ship- board Scientific Party (1992). Twelve circular areas of approximately $23.3 \mathrm{~mm}^{2}$ were chosen from each thin section. Selection of measured areas was made so as not to overlap each other, and to minimize the area occupied by phenocrysts. The length and width of the largest crystals of plagioclase and magnetite were measured. The longest extensions of plagioclase and magnetite are measured as the length, and the widths are measured perpendicular to elongation at the widest portion of the crystals. Tails attached to some euhedral plagioclase are not measured. Measurement was repeated in every circle, and the largest and smallest values among the 12 measurements were excluded; the remaining 10 values were then averaged as the maximum grain size. Very fine-grained or aphanitic samples taken from chilled margins of dikes were not measured. The results of the measurement are given in Table 1.

Figure 2 shows crystal size distribution (CSD; Marsh, 1988) of a representative diabase sample in order to assess the maximum grain size measured as such. Although the data are rather scattered, the CSD shows an almost linear variation as is often observed in volcanic rocks (Cashman and Marsh, 1988). Because of a limited size of a thin section of an individual specimen, the number of crystals measured is smaller than usually used for crystal size distribution plots, which do not give an accurate number for larger crystals. However, the change in the slope reflects change in growth rate or crystallization time of plagioclase crystals and the inflection at length $=0.16 \mathrm{~cm}$ corresponds to the maximum length of plagioclase probably crystallized during the groundmass stage. This value is almost equal to the maximum plagioclase length of $0.14 \mathrm{~cm}$ measured as described above.

Lengths of plagioclase vs. magnetite, and diameters of circles with equivalent areas (EQD) to the plagioclase and magnetite crystals, are plotted in Figures $3 \mathrm{~A}$ and $3 \mathrm{~B}$. The lengths and EQD of plagioclase and magnetite are roughly correlated.

Variation in the grain size of plagioclase and magnetite with depth from 894 to 2000 mbsf for Leg 140, together with the previous Legs 83 and 111, are plotted in Figure 4. The maximum plagioclase length gradually decreases through the lava/sheeted dikes transition zone down to 1360 mbsf, although EQD remains almost constant. This means that plagioclase crystals are very narrow and elongated through the transition zone and in the shallower parts of the dike swarm, presumably due to rapid crystal growth under a larger rate of cooling. 


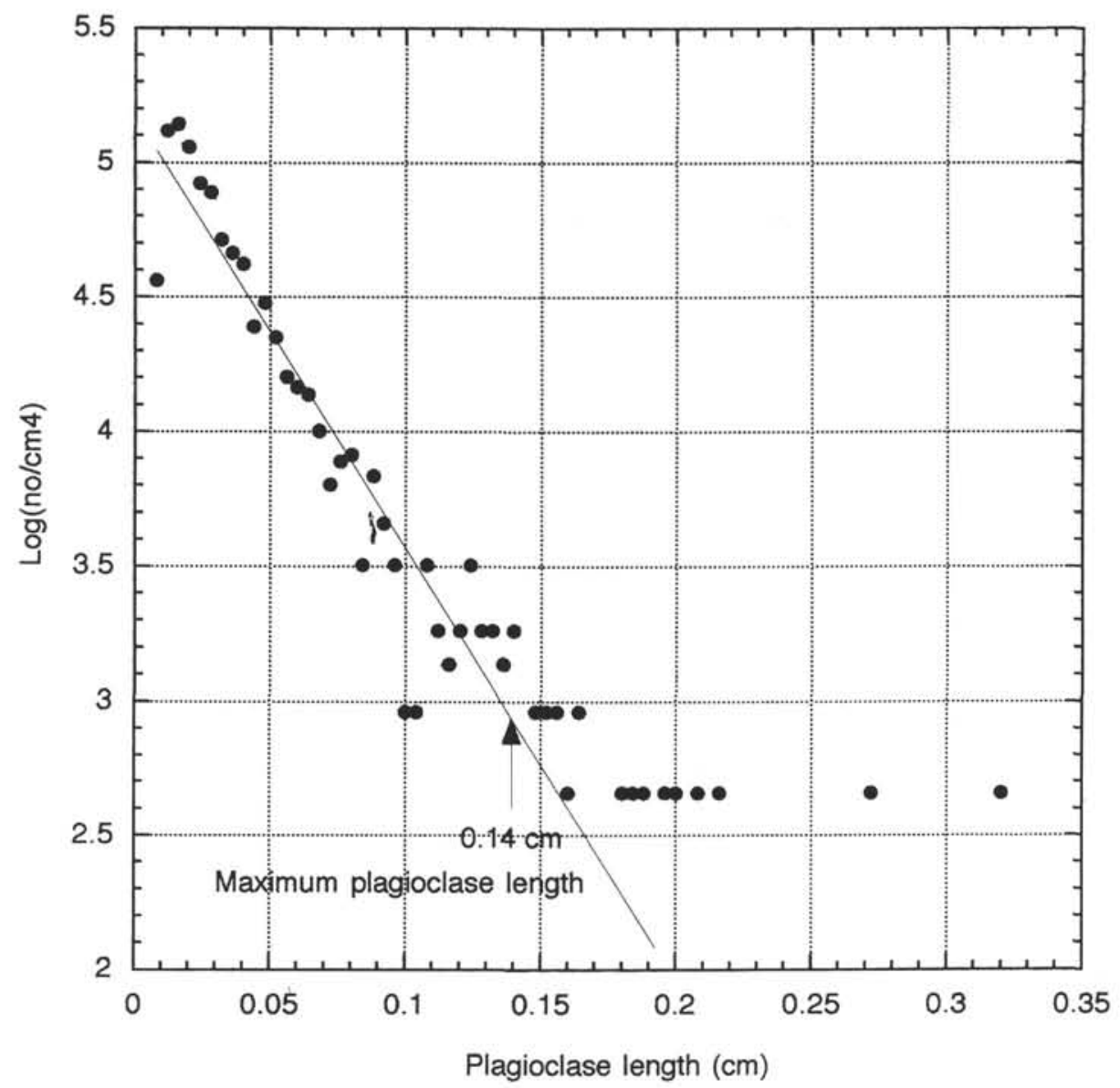

Figure 2. Plagioclase length distribution of dike Sample 140-504B-227R-1, 83-85 cm. 2021 plagioclase crystals in $163 \mathrm{~mm}^{2}$ of a thin section were measured, and the number of crystals per unit length per unit area were raised to the $3 / 2$ power as described in Cashman and Marsh (1988). The regression line for the data points with length smaller than $0.16 \mathrm{~cm}$ has the $y$-intercept of $1.49 \times 10^{5}$, and the slope is $-16.08 \mathrm{~cm}^{-1}$. The maximum plagioclase length, determined as described in the text, is $0.14 \mathrm{~cm}$, which is slightly smaller than the inflection of the slope at length $=0.16 \mathrm{~cm}$.

A

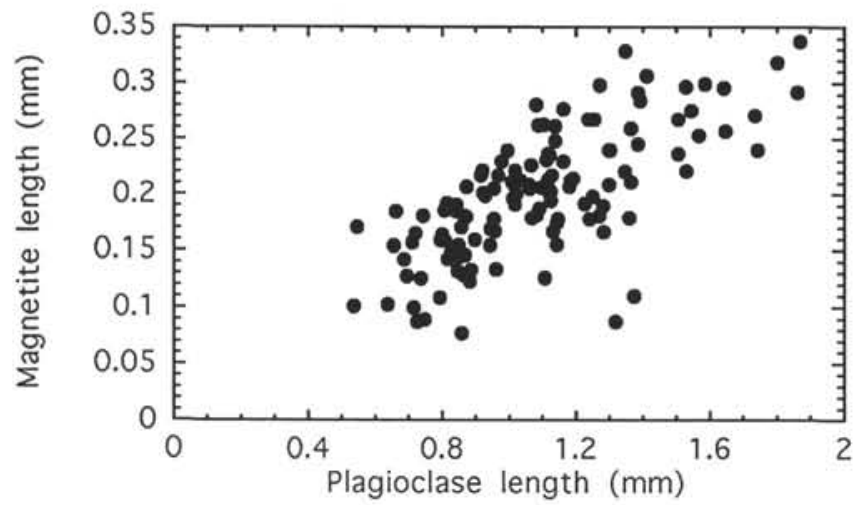

B

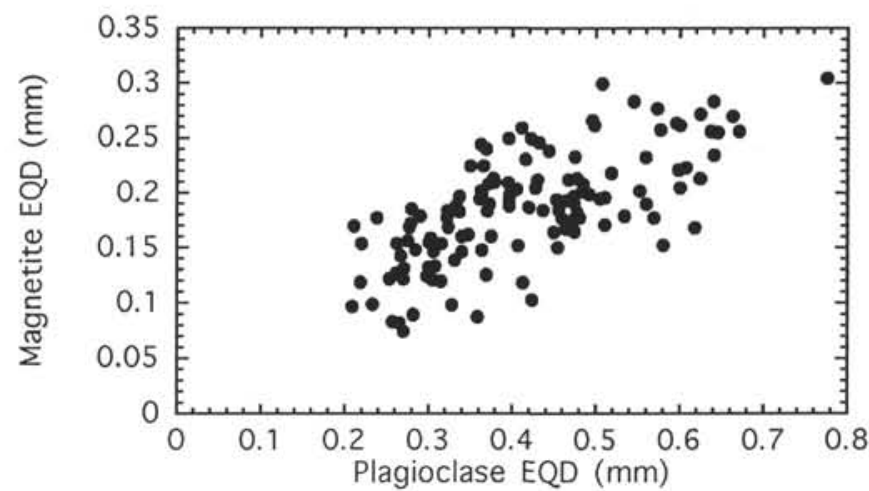

Figure 3. Correlation between sizes of groundmass plagioclase and magnetite. A. Plot of the maximum lengths. B. Plot of diameters with equivalent area (EQD) to the crystals.

The most noticeable feature shown by the grain-size variation below 1570 mbsf is a crude zig-zag pattern, which is best shown by the variation in the maximum plagioclase length (Fig. 5A, -B). The maximum plagioclase length consists of gradual decreases and abrupt jumps downhole from 1570 to $1750 \mathrm{mbsf}$. Such a systematic variation is not observed deeper, but there are some jumps in the grain size which disrupt gradual increases or decreases. As shown in Figure 5B, the zig-zag pattern is an inter-unit variation except that from 1709 to 1718 mbsf, which belongs to a single unit 232 .

Grain size in a dike is controlled by the melt composition (and hence, the phase relations of crystallizing phases), the cooling rate and the temperature contrast between the magma and the wall rock. The studied samples have similar chemical compositions $\left(\mathrm{SiO}_{2} 50 \pm 1\right.$ $\mathrm{wt} \%)$, and the growth rate of plagioclase is almost constant in the 


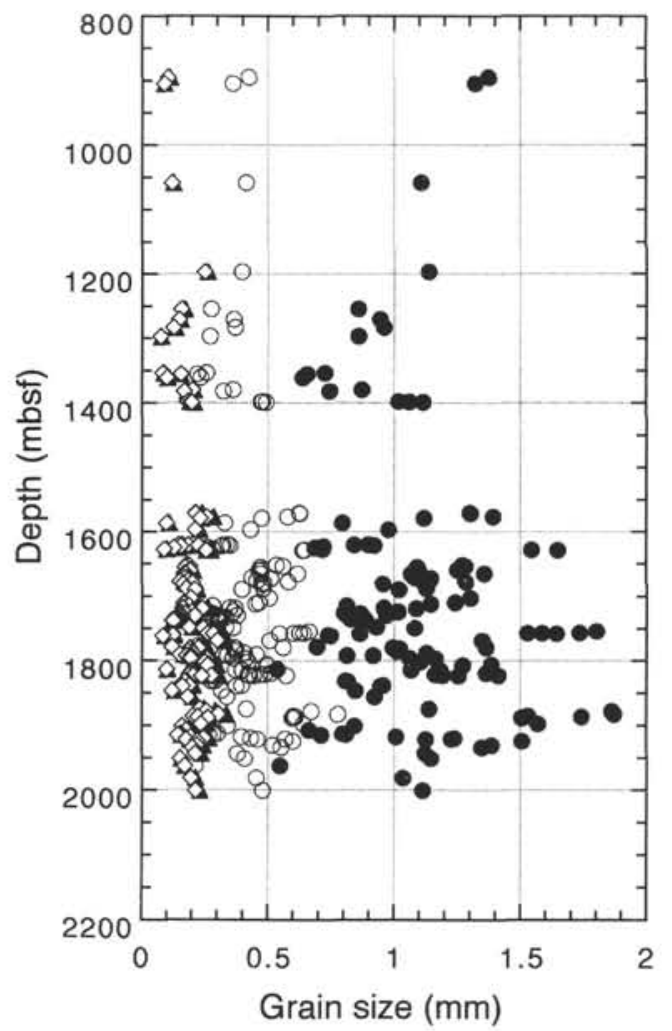

Figure 4. Downhole variation in the size of plagioclase and magnetite in the groundmass with depth below seafloor for the dikes near the base of the extrusive layers and through the sheeted dike sections drilled on Legs 83,111, and 140. Plagioclase length = solid circles; plagioclase EQD = open circles; magnetite length $=$ solid triangles; magnetite $\mathrm{EQD}=$ open diamonds.

compositional ranges from basaltic and andesitic magmas (Cashman, 1990). The cooling rate of a dike is a function of the melt composition, the temperature contrast and the width of the dike. Figure 6 is a plot of the maximum lengths of plagioclase and magnetite vs. dike width. The grain size does not show any systematic increase with dike width. The temperature of the wall rocks at the time of dike injection increases downward, so that the coarsest sample from each lithologic unit should ideally increase in the grain size with the depth. However, the inter-unit variations of the grain size exhibit a zig-zag pattern consisting of steady increases or decreases and abrupt jumps. Thus, the downhole variation in the grain size is apparently not due to the difference in the melt compositions, dike width, nor the rise in the wall rock temperature.

The shipboard scientific party attributed these grain-size variations to those arising through a series of cross-cutting multiple dikes (Shipboard Scientific Party, 1992). The existence of multiple dikes is inferred by a few contacts between adjacent dikes and within-unit grain size variations, which show only one-way chilling and coarsening toward the other direction. Multiple dikes are well documented in the sheeted dikes of some ophiolites (e.g., Troodos Ophiolite; Baragar et al., 1990) and continental flood basalt provinces (Gautneb and Gudmundsson, 1992), which were formed under extensional regional stress fields. A multiple dike is formed when new batches of magma intrude into the center of the previous dike. A few chilled contacts recovered on this leg are either sharp, rigid, or irregular and wavy, indicating that later dikes are emplaced at or below the solidus temperature. Some cores contain deformed cognate inclusions apparently derived from semisolidified wall rocks, but such cores are limited to coarse-grained central portions of multiple dike units. This suggests that repeated injection of dikes would have, in effect, thermally insulated and reduced the cooling rate of the later emplaced dikes. As a result, the multiple dikes are coarser grained toward the center of the dike units and form apparent single cooling units (Fig. 7). The steady increases and decreases in the inter-unit grain size are variations through such multiple dikes, which are interrupted by another set of multiple dike units, resulting in abrupt jumps in the grain size. This indicates that the site of dike intrusion jumps from time to time and a new injection of dikes sometimes disrupts or destructs older multiple dike units. Thus, the downhole sections do not always have sets of complete multiple dikes but only aggregates of partly destroyed, incomplete multiple dike units.

Through the 430-m-long sections drilled during Legs 137 and 140 , at least 16 cooling units are identified, on the basis of jumps and continuity in grain size (i.e., decrease in the maximum plagioclase length is gradual from lithologic Units 193 to 211 , but interrupted by an abrupt jump at Unit 213). Although there is no measurement on a thin section of the lithologic Unit 212, the measurement on the cored sample under a binocular microscope show no abrupt jump in plagioclase size. Therefore, the cooling unit boundary is defined here. From Unit 213 to 228 , the plagioclase length again appears to decrease continuously. However, Units 214-217 are so fine grained that they are not measured. Thus, Unit 213 is not included in the same cooling unit as the lower units. As already mentioned, whole-rock compositions of the cored samples are moderately uniform and there is no apparent difference between the cooling units. Among the 16 cooling units, only the fifth and the tenth units from the top show well-defined grain-size variations (Table 2). Cooling Unit 5 consists of six lithologic units, although the grain size of lithologic Unit 225 is not determined (Fig. 8A). Within-unit variations are observed in Units 223 and 227; however, the largest size in each unit steadily increases from Unit 227 to 222 . Variations in the cooling Unit 10 is not so good as in the cooling Unit 5 (Fig. 8B). Unit 242 is a very fine-grained rock which is apparently taken from a chilled margin. Unit 243 is also smaller than neighboring units on both sides. This may be due to a problem in sampling. The sample may not have been taken from the coarsest part of the Unit 243. Besides these two, the largest grain size in each unit gradually increases from Unit 239 to 244.

\section{MODELING OF SOLIDIFICATION OF MULTIPLE DIKES}

To simulate solidification of multiple dikes, a numerical approach was made to a simple one-dimensional conductive cooling model. I assume that magma is emplaced and solidifies at a constant temperature $T_{m}$, and latent heat is released at this temperature. The host rock has the initial temperature $T_{w}$, which is modified by the injection of multiple dikes. Because almost all samples have phenocrysts of plagioclase + augite \pm olivine and crystallized plagioclase and augite as the groundmass minerals, they are already saturated with the latter two phases at the time of emplacement. The magma continues to crystallize until the solidification front passes through into the interior of the dike. Thus, the time required for crystallization is equal to that for solidification. In the following calculations, $T_{m}$ is taken to be $1000^{\circ} \mathrm{C}$, and latent heat of crystallization and heat capacity are assumed to be $320 \mathrm{~kJ} / \mathrm{kg}$ and $1.2 \mathrm{~kJ} / \mathrm{kg} \times{ }^{\circ} \mathrm{K}$, respectively (Turcotte and Schubert, 1982). The time for crystallization calculated as such tends to be underestimated than a model including kinetic effects and the deviation becomes larger as the wall rock temperature is closer to that of the magma (Spohn et al., 1988). The crystallization time may be underestimated by up to $35 \%$ when $T_{w} / T_{m}=0.35$. However, as will be discussed later, $T_{w} / T_{m}$ of the Hole $504 \mathrm{~B}$ dikes is approximately 0.25 and the deviation from the model of Spohn et al. is not significant. The amount of underestimation will be only on the order of $10 \%$.

For crystallization of a simple dike, this is the same as the problem for which Stefan first obtained the solution. Figure 9 illustrates temperature profiles through a simple dike and an adjacent wall rock. In a simple dike, the first $1 \mathrm{~m}$ solidifies in 10 days, but it takes 40 days for solidification of $2 \mathrm{~m}$, and 91 days for $3 \mathrm{~m}$. 
A

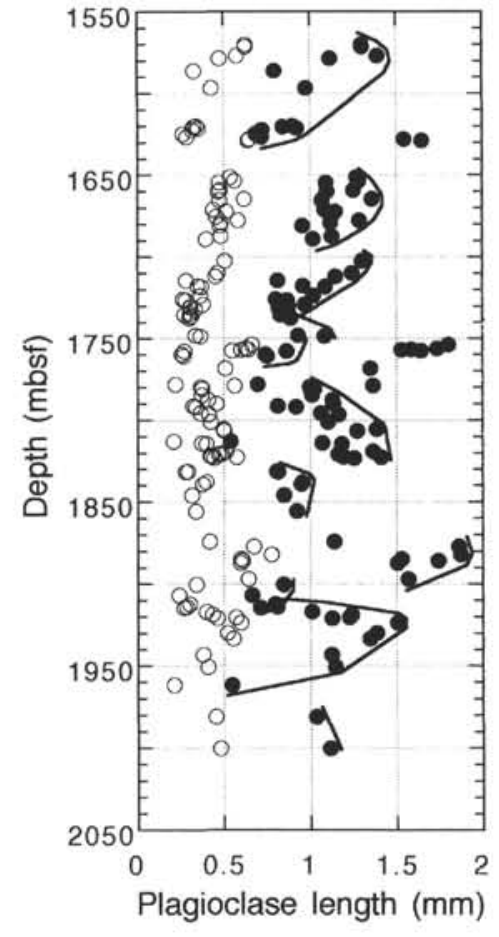

B

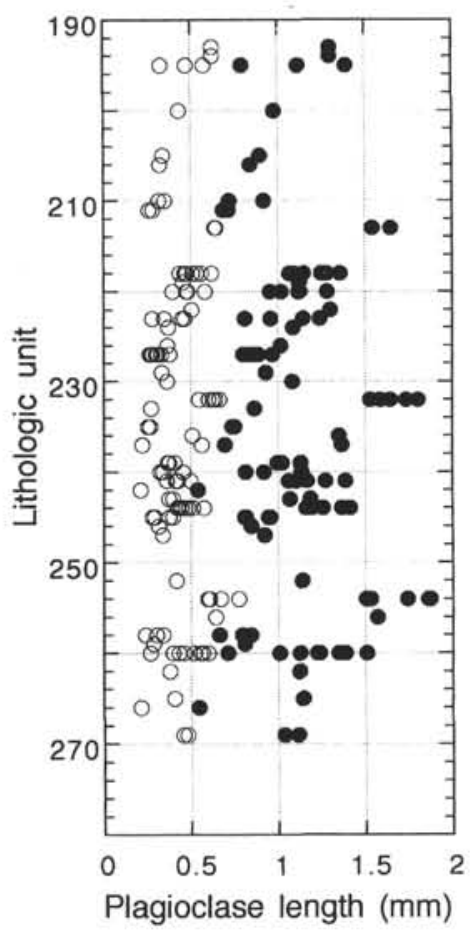

Figure 5. Downhole variation in the size of plagioclase in the groundmass drilled in Legs 137 and 140, plotted against depth (A) and lithologic units (B). Symbols are as in Figure 4. Cooling units are shown by curves on (A).

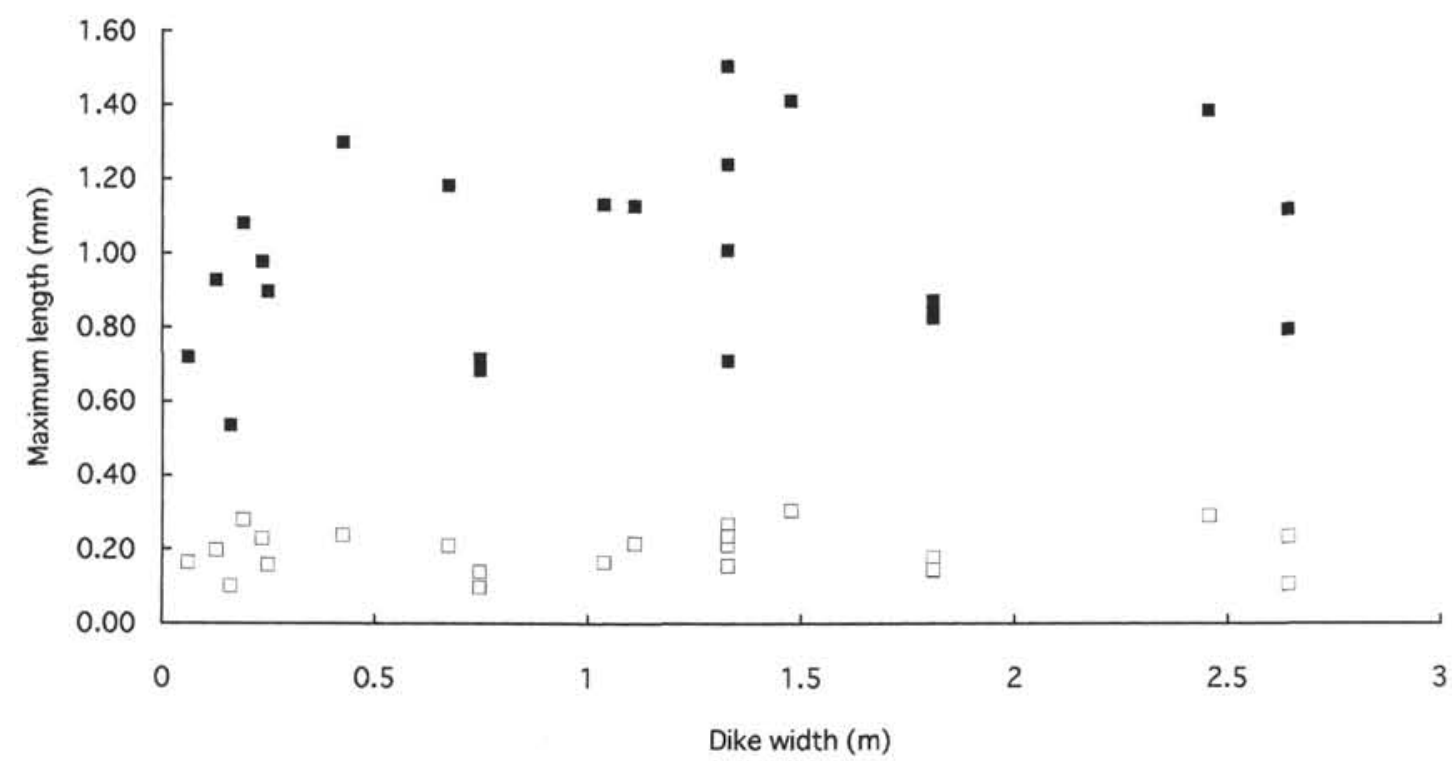

Figure 6. The maximum plagioclase (solid squares) and magnetite (open squares) lengths plotted against width of dikes. The crystal length is rather scattered and does not show any systematic correlation with dike width except for thinner than $0.5 \mathrm{~m}$.

Because dikes follow the pathway of least work, the center of the previous dike would be preferred for thermal reasons. Therefore, I assume that new pulses of magmas are injected at the center of the previous dikes. Crystallization of the second dike is different from the first one because the latter is now a part of the wall rock which is heated up by the second injection, and the temperature distribution through the new wall rock differs from the initial temperature profile through the original wall rock. As the injection is repeated, the time required for the crystallization for the identical thickness of the later dikes is prolonged compared to that for the first one. However, the later dikes do not always take longer time to crystallized than the previous one because the crystallization time of the individual dikes within a multiple dike unit depends on the temperature profile when the dike was emplaced.

For the simulation of multiple injections, two cases are considered: In the first case, new magma injection occurs when the previous dike has solidified and cooled to a constant temperature slightly below the solidus. Some chilled contacts recovered on Leg 140 show plastic deformations and engulfments of the host dikes. Such features suggest that the new injection occurs before the complete solidification or just after the solidification of the old dikes when the wall rock is still plastic. Figures $10 \mathrm{~A}$ and $10 \mathrm{~B}$ are the results of solidification of 
Table 1. Results of grain size measurements from Hole 504B.

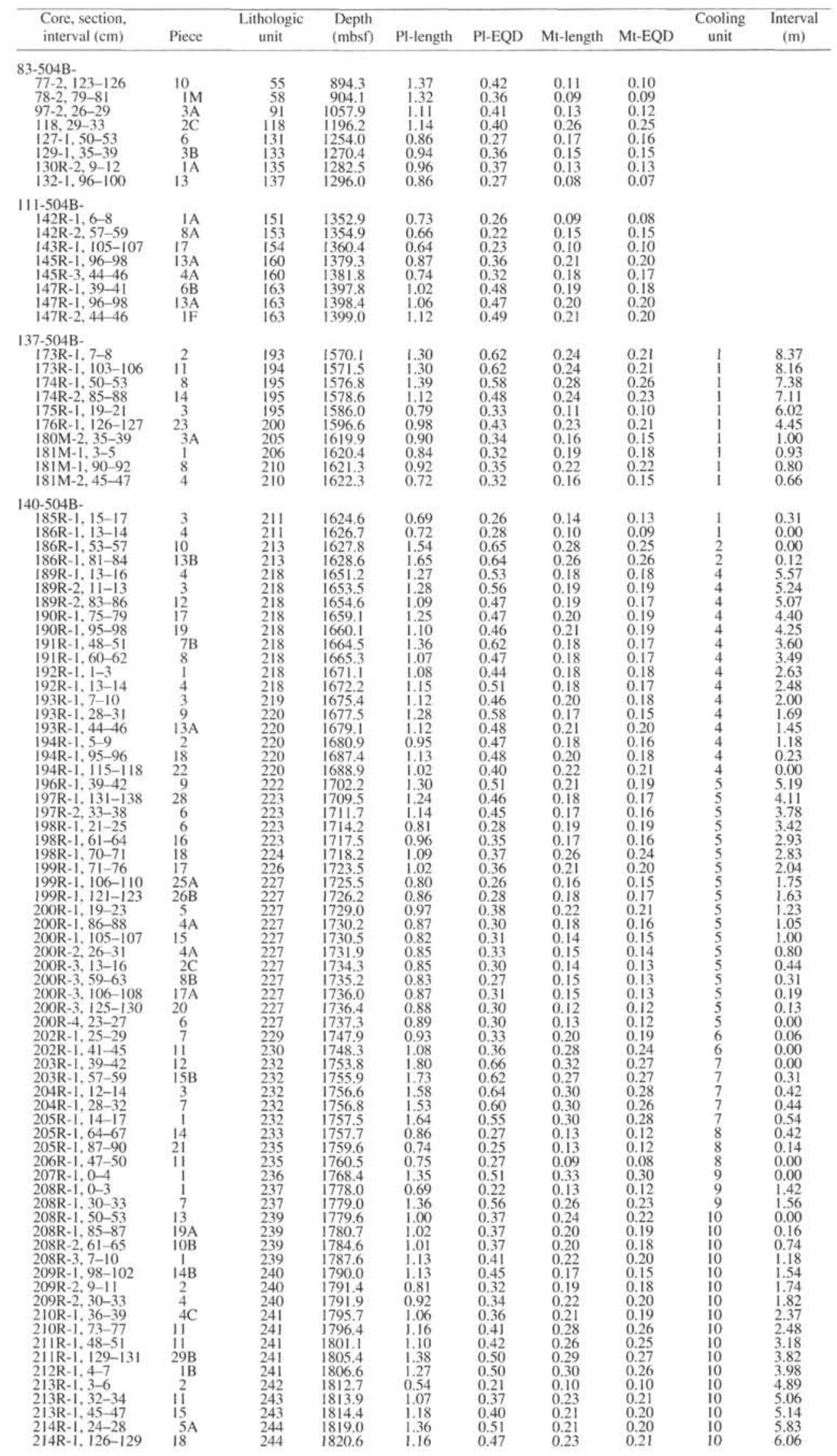


Table 1 (continued).

\begin{tabular}{|c|c|c|c|c|c|c|c|c|c|}
\hline $\begin{array}{l}\text { Core, section, } \\
\text { interval }(\mathrm{cm})\end{array}$ & Piece & $\begin{array}{l}\text { Lithologic } \\
\text { unit }\end{array}$ & $\begin{array}{l}\text { Depth } \\
\text { (mbsf) }\end{array}$ & Pl-length & Pl-EQD & Mt-length & Mt-EQD & $\begin{array}{c}\text { Cooling } \\
\text { unit }\end{array}$ & $\begin{array}{l}\text { Interval } \\
\text { (m) }\end{array}$ \\
\hline $214 \mathrm{R}-1,130-132$ & 25 & 244 & 1820.7 & 1.16 & 0.48 & 0.23 & 0.21 & 10 & 6.07 \\
\hline $214 \mathrm{R}-2,29-32$ & 7 & 244 & $\begin{array}{l}1820.1 \\
1821.4\end{array}$ & $\begin{array}{l}1.10 \\
1.18\end{array}$ & 0.42 & 0.21 & 0.19 & 10 & 6.07 \\
\hline $214 R-2,88-90$ & 20 & 244 & 1822.3 & 1.19 & 0.43 & 0.21 & 0.20 & 10 & 6.31 \\
\hline $214 \mathrm{R}-2,100-103$ & 22 & 244 & 1822.5 & 1.41 & 0.57 & 0.31 & 0.28 & 10 & 6.34 \\
\hline $215 \mathrm{R}-1,0-4$ & 1 & 244 & 1823.1 & 1.26 & 0.44 & 0.27 & 0.24 & 10 & 6.43 \\
\hline $216 \mathrm{R}-1,58-60$ & 13 & 245 & 1831.2 & 0.81 & 0.29 & 0.19 & 0.18 & 11 & 3.61 \\
\hline $216 \mathrm{R}-1,66-68$ & 14 & 245 & 1831.6 & 0.81 & 0.28 & 0.19 & 0.17 & 11 & 3.55 \\
\hline $217 \mathrm{R}-1,0-2$ & 1 & 245 & 1837.8 & 0.96 & 0.40 & 0.20 & 0.19 & 11 & 2.64 \\
\hline $217 \mathrm{R}-1,4-6$ & 1 & 245 & 1839.2 & 0.95 & 0.37 & 0.17 & 0.16 & 11 & 2.43 \\
\hline $217 R-1,23-26$ & 6 & 246 & 1846.0 & 0.85 & 0.31 & 0.13 & 0.12 & 11 & 1.42 \\
\hline $218 \mathrm{R}-1,24-27$ & 7 & 247 & 1855.6 & 0.92 & 0.34 & 0.20 & 0.18 & 11 & 0.00 \\
\hline $220 \mathrm{R}-1,27-30$ & 7 & 252 & 1874.1 & 1.14 & 0.42 & 0.25 & 0.23 & 12 & 0.00 \\
\hline $221 \mathrm{R}-1,11-15$ & 4 & 254 & 1877.2 & 1.86 & 0.67 & 0.29 & 0.26 & 13 & 2.93 \\
\hline $221 \mathrm{R}-1,40-44$ & 10 & 254 & 1882.0 & 1.87 & 0.78 & 0.34 & 0.30 & 13 & 2.22 \\
\hline $222 \mathrm{R}-1,0-4$ & 1 & 254 & 1884.7 & 1.53 & 0.60 & 0.22 & 0.20 & 13 & 1.81 \\
\hline $222 \mathrm{R}-1,17-19$ & IE & 254 & 1885.9 & 1.74 & 0.61 & 0.24 & 0.22 & 13 & 1.65 \\
\hline $222 \mathrm{R}-1,37-39$ & 6 & 254 & 1887.3 & 1.51 & 0.60 & 0.27 & 0.26 & 13 & 1.44 \\
\hline $222 \mathrm{R}-1,129-132$ & 24 & 256 & 1897.0 & 1.57 & 0.64 & 0.25 & 0.23 & 13 & 0.00 \\
\hline $223 \mathrm{R}-1,20-23$ & 6 & 258 & 1900.2 & 0.84 & 0.34 & 0.19 & 0.16 & 14 & 1.98 \\
\hline $224 \mathrm{R}-1,21-24$ & 1 & 258 & 1906.8 & 0.66 & 0.24 & 0.18 & 0.18 & 14 & 1.00 \\
\hline $224 \mathrm{R}-1,59-62$ & 14 & 258 & 1912.1 & 0.80 & 0.30 & 0.16 & 0.15 & 14 & 0.22 \\
\hline $225 \mathrm{R}-1,40-44$ & 10 & 259 & 1913.6 & 0.81 & 0.28 & 0.16 & 0.15 & 14 & 0.00 \\
\hline $225 \mathrm{R}-1,59-61$ & 14 & 260 & 1914.2 & 0.71 & 0.27 & 0.16 & 0.14 & 15 & 7.02 \\
\hline 225R-1, $137-139$ & 34 & 260 & 1916.8 & 1.01 & 0.40 & 0.21 & 0.19 & 15 & 6.63 \\
\hline $225 \mathrm{R}-2,42-44$ & 7 & 260 & 1918.7 & 1.24 & 0.43 & 0.27 & 0.25 & 15 & 6.36 \\
\hline $226 \mathrm{R}-1,16-20$ & 3 & 260 & 1920.3 & 1.23 & 0.57 & 0.19 & 0.18 & 15 & 6.12 \\
\hline $226 \mathrm{R}-1,61-63$ & 12 & 260 & 1920.9 & 1.13 & 0.46 & 0.19 & 0.18 & 15 & 6.03 \\
\hline $226 R-2,77-79$ & 10 & 260 & 1923.4 & 1.51 & 0.60 & 0.24 & 0.22 & 15 & 5.66 \\
\hline $227 \mathrm{R}-1,83-85$ & 10 & 260 & 1929.8 & 1.39 & 0.52 & 0.24 & 0.22 & 15 & 4.72 \\
\hline $227 \mathrm{R}-2,0-5$ & 1 & 260 & 1933.2 & 1.35 & 0.55 & 0.22 & 0.20 & 15 & 4.22 \\
\hline $228 \mathrm{R}-1,55-57$ & 13 & 262 & 1943.2 & 1.12 & 0.38 & 0.23 & 0.21 & 15 & 2.74 \\
\hline $229 \mathrm{R}-1,34-37$ & 10 & 265 & 1950.7 & 1.14 & 0.41 & 0.16 & 0.15 & 15 & 1.63 \\
\hline $233 \mathrm{R}-1,4-7$ & 2 & 266 & 1961.7 & 0.55 & 0.21 & 0.17 & 0.17 & 15 & 0.00 \\
\hline $236 \mathrm{R}-1,0-4$ & 1 & 269 & 1980.8 & 1.03 & 0.45 & 0.21 & 0.19 & 16 & 0.00 \\
\hline $238 \mathrm{R}-1,22-25$ & 8 & 269 & 2000.2 & 1.11 & 0.48 & 0.23 & 0.21 & 16 & 2.87 \\
\hline
\end{tabular}

Notes: $\mathrm{PI}=$ plagioclase; $\mathrm{Mt}=$ magnetite; $\mathrm{EQD}=$ diameter of a sphere with an equivalent area. Length and $\mathrm{EQD}$ are in millimeters. Intervals are calculated on the basis of the average dip of $81.5^{\circ}$.

\section{Intrusion of multiple dikes}

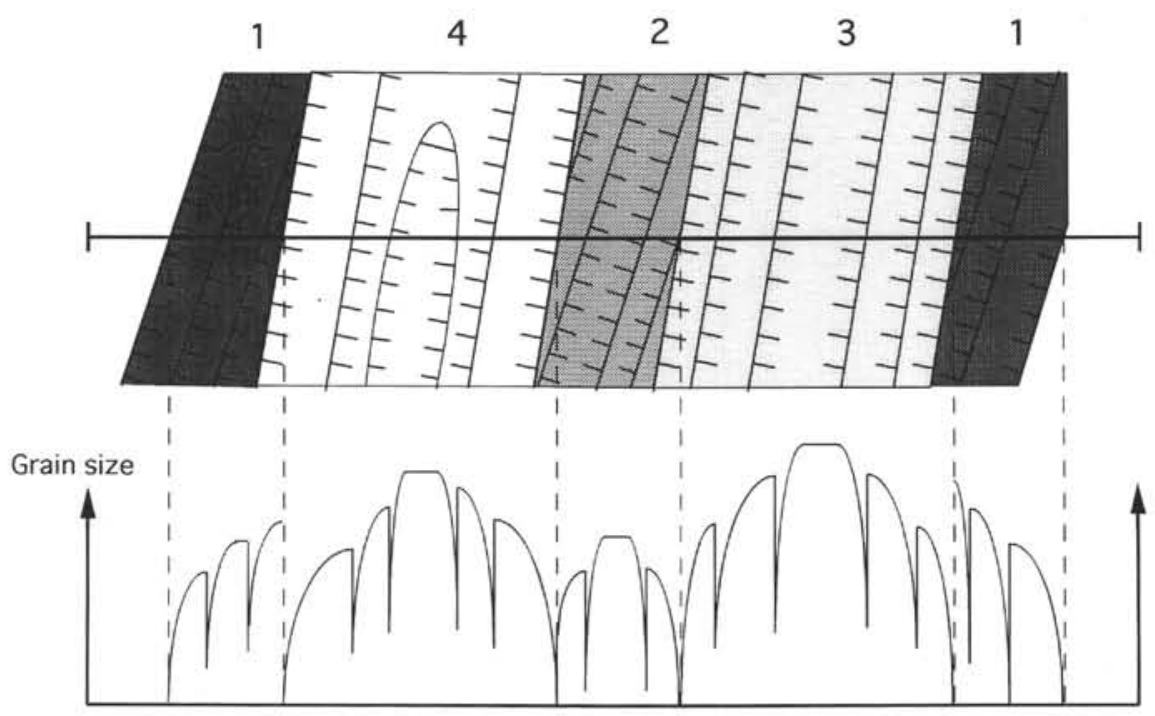

Figure 7. Schematic model of multiple dike formation. Numbers indicate orders of intrusion. The site of multiple intrusion shifts within a certain range of the volcanic zone, destroying the previous multiple dike units. Although the grain size increases toward the center of each multiple dike, occasional jumps in grain size are seen in the section where older multiple dike units are disrupted by later dikes.

such a multiple dike. Each dike has a width of $1 \mathrm{~m}$, and solidifies and cools to $800^{\circ} \mathrm{C}$ before the injection of the next dike. The first dike solidifies in 2 days, and cools to $800^{\circ} \mathrm{C}$ in $76 \mathrm{hr}$. The second dike solidifies in 7 days and 10 days after the emplacement of the first dike. The third dike solidifies in 9 days. Thus, the solidification time is prolonged for later dikes due to heating up by repeated injection.

Figure 11 shows the time required for solidification of the simple dike and those for solidification and cooling of the multiple dike with each expanding by $1 \mathrm{~m}$. The solidification time for every $0.5-\mathrm{m}$ width of the simple dike becomes progressively longer as solidification proceeds. On the contrary, a notable increase in the solidification time is recognized only for the first three dikes of the multiple dike unit. Later dikes do not have as prolonged a solidification time as the simple dike. Instead, the time to cool to $800^{\circ} \mathrm{C}$ becomes significantly longer as the intrusion of the dike is repeated. This is because in the first model the wall-rock temperature is assumed to be constant whenever the new 
A

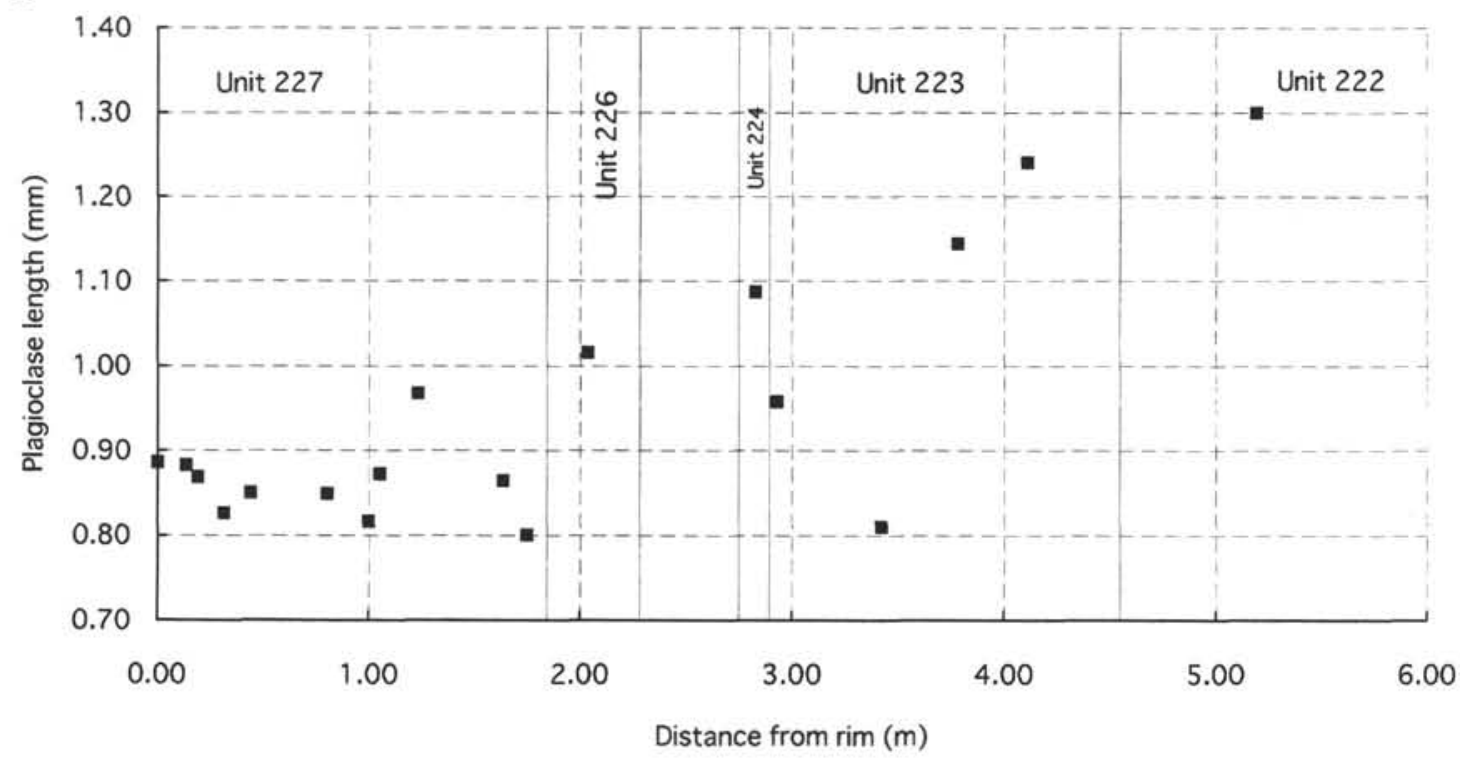

Figure 8. Variation of the maximum length of plagioclase through cooling Unit 5 (A) and Unit 10 (B). Although the grain size is slightly scattered, the largest grain size in individual lithologic units monotonously increases with distance from the rim of the multiple dike unit. An exception is lithologic Unit 242 in cooling Unit 10 (B), which is too fine-grained and is apparently taken from a chilled contact.

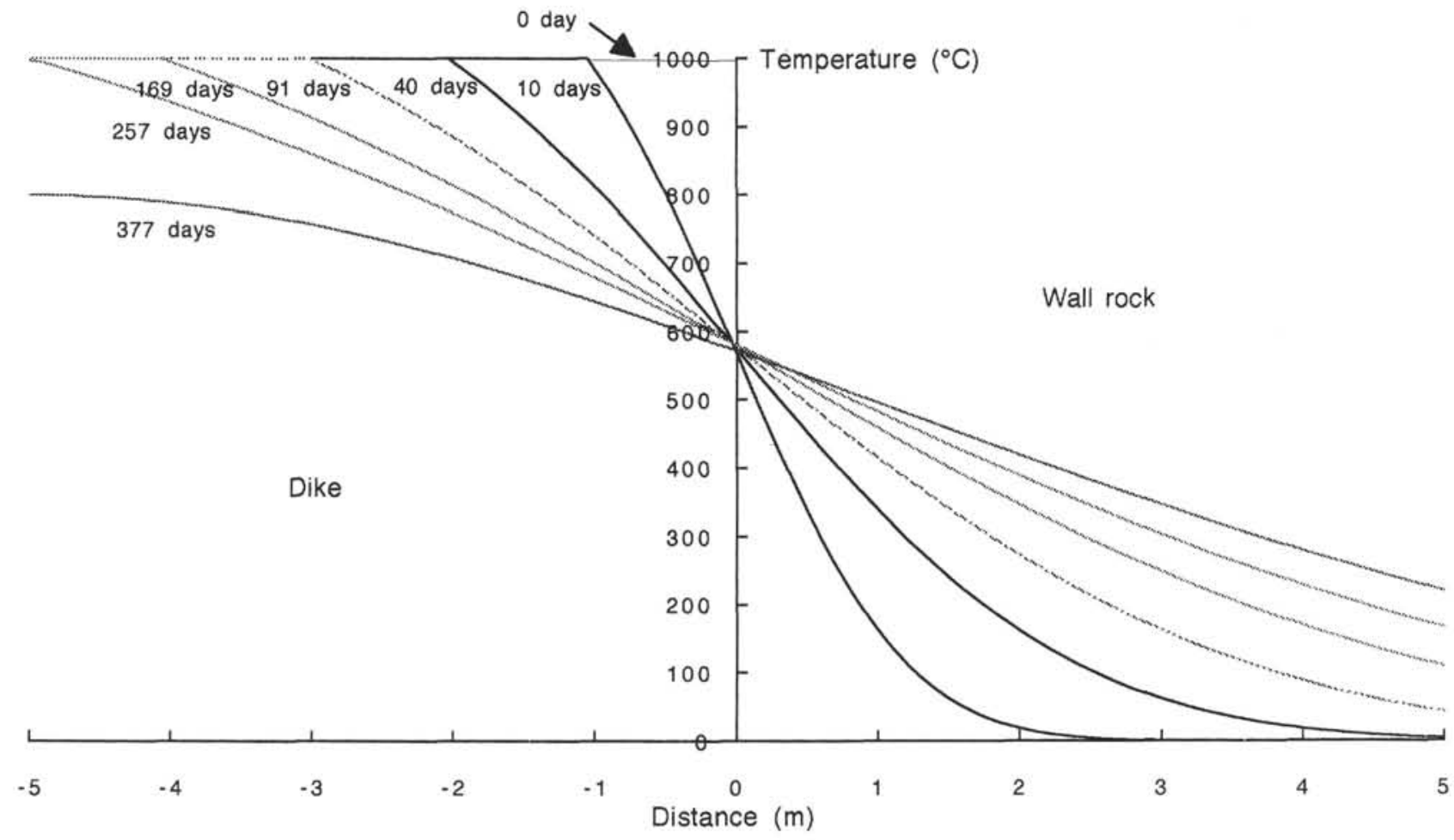

Figure 9. Solidification of a single dike emplaced in the host rock with the same physical properties as the dike. Temperature profiles at various times through the dike (left) and adjacent wall rock (right) are shown.

injection occurs. As exemplified by cooling Units 5 and 10, the grain size is coarser in the inner dikes than in the outer ones. This suggests that the crystallization time becomes longer toward the center of the multiple dikes. Therefore, the assumption of constant temperature prior to new injection is not appropriate when the progressive increase in grain size toward the center of the multiple dike units is observed.
Dike intrusions observed in fissure swarms beneath active volcanoes such as Krafla, Iceland, and Kilauea, Hawaii, show that such intrusions continue for as long as one week and are repeated several tens of times with intervening quiescent periods ranging from 1 to 18 months. So, let us consider a case in which dike intrusion occurs periodically at a constant time interval. 
B

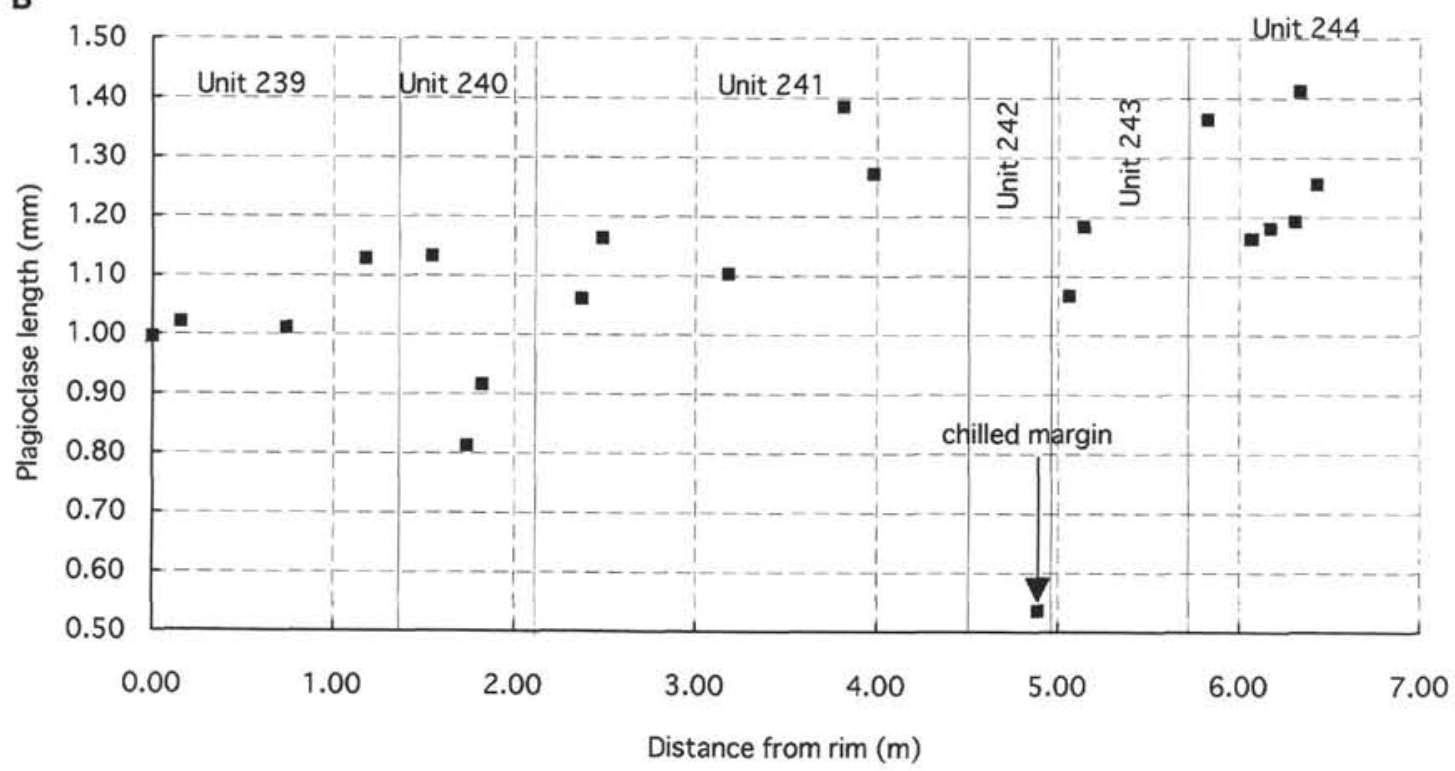

Figure 8 (continued).

Table 2. Width of cooling units at minimum, average, and maximum dike dips.

\begin{tabular}{|c|c|c|c|c|c|c|c|c|}
\hline \multirow[b]{2}{*}{$\begin{array}{c}\text { Cooling } \\
\text { unit }\end{array}$} & \multirow[b]{2}{*}{$\begin{array}{c}\text { Lithologic } \\
\text { unit }\end{array}$} & \multirow[b]{2}{*}{$\begin{array}{l}\text { Depth } \\
\text { (mbsf) }\end{array}$} & \multicolumn{2}{|c|}{ Minimum dip $79^{\circ}$} & \multicolumn{2}{|c|}{ Average dip $81.5^{\circ}$} & \multicolumn{2}{|c|}{ Maximum dip $84^{\circ}$} \\
\hline & & & $\begin{array}{l}\text { Width } \\
(\mathrm{m})\end{array}$ & $\begin{array}{l}\text { Width } \times 2 \\
\text { (m) }\end{array}$ & $\begin{array}{l}\text { Width } \\
(\mathrm{m})\end{array}$ & $\underset{(\mathrm{m})}{\text { Width } \times 2}$ & $\begin{array}{c}\text { Width } \\
\text { (m) }\end{array}$ & $\begin{array}{c}\text { Width } \times 2 \\
(\mathrm{~m})\end{array}$ \\
\hline 1 & \multirow{16}{*}{$\begin{array}{l}193 \\
212 \\
213 \\
213 \\
214 \\
217 \\
218 \\
221 \\
222 \\
228 \\
229 \\
231 \\
232 \\
232 \\
233 \\
235 \\
236 \\
238 \\
239 \\
244 \\
245 \\
250 \\
251 \\
253 \\
254 \\
256 \\
257 \\
259 \\
260 \\
266 \\
267 \\
269\end{array}$} & \multirow{16}{*}{$\begin{array}{l}1570.10 \\
1627.28 \\
1627.28 \\
163.00 \\
1632.00 \\
1651.06 \\
1651.06 \\
1697.34 \\
1697.34 \\
1747.20 \\
1747.20 \\
1752.81 \\
1752.81 \\
1758.83 \\
1758.83 \\
1768.40 \\
1768.40 \\
1779.52 \\
1779.52 \\
1829.22 \\
1829.22 \\
1865.50 \\
1865.50 \\
1876.83 \\
1876.83 \\
1897.24 \\
1897.24 \\
1916.40 \\
1916.40 \\
1976.10 \\
1976.10 \\
2000.40\end{array}$} & 10.91 & 21.82 & 8.45 & 16.90 & 5.98 & 11.95 \\
\hline 2 & & & 0.90 & 1.80 & 0.70 & 1.40 & 0.49 & 0.99 \\
\hline 3 & & & 3.64 & 7.27 & 2.82 & 5.64 & 1.99 & 3.99 \\
\hline 4 & & & 8.83 & 17.66 & 6.84 & 13.68 & 4.84 & 9.67 \\
\hline 5 & & & 9.51 & 19.03 & 7.37 & 14.74 & 5.21 & 10.42 \\
\hline 6 & & & 1.07 & 2.14 & 0.83 & 1.66 & 0.59 & 1.17 \\
\hline 7 & & & 1.15 & 2.30 & 0.89 & 1.78 & 0.63 & 1.26 \\
\hline 8 & & & 1.83 & 3.65 & 1.41 & 2.83 & 1.00 & 2.00 \\
\hline 9 & & & 2.12 & 4.24 & 1.64 & 3.29 & 1.16 & 2.32 \\
\hline 10 & & & 9.48 & 18.97 & 7.35 & 14.69 & 5.20 & 10.39 \\
\hline 11 & & & 6.92 & 13.84 & 5.36 & 10.72 & 3.79 & 7.58 \\
\hline 12 & & & 2.16 & 4.33 & 1.68 & 3.35 & 1.18 & 2.37 \\
\hline 13 & & & 3.89 & 7.79 & 3.02 & 6.03 & 2.13 & 4.27 \\
\hline 14 & & & 3.66 & 7.31 & 2.83 & 5.67 & 2.00 & 4.01 \\
\hline 15 & & & 11.39 & 22.78 & 8.82 & 17.65 & 6.24 & 12.48 \\
\hline 16 & & & 4.64 & 9.27 & 3.59 & 7.18 & 2.54 & 5.08 \\
\hline & & Average & 5.13 & 10.26 & 3.98 & 7.95 & 2.81 & 5.62 \\
\hline
\end{tabular}

Notes: Time interval of rifting: Minimum dip $=10.26+0.07=147 \mathrm{yr}$, average dip $=7.95+0.07=114 \mathrm{yr}$; maximum dip $=5.62 \div 0.07=80 \mathrm{yr}$.

Figure 12 shows the temperature at the dike center for intrusion of $1.5-\mathrm{m}$-wide dikes at an interval of 3 months. The first dike solidifies as soon as that of the first model but it has a longer time for cooling down to $250^{\circ} \mathrm{C}$ before the next injection. The second dike intrudes and solidifies as soon as the first dike, but it cools to only $400^{\circ} \mathrm{C}$. As the intrusion is repeated, temperature just prior to the new injection becomes higher, and the crystallization time becomes longer.

When the multiple injection occurs at an interval of 1 month, the host rock temperature increases more rapidly than in the case for the 3-month injection because the time for cooling is much shorter than the latter. Although the second, third, and fourth dike intrudes after the solidification of the previous dikes, the fifth dike intrudes shortly after the solidification of the fourth one. Finally, the sixth and later dikes intrude before the solidification of the previous ones, and thus new injection of magma merely expands the width of the dike and no more chilled margins are formed.

Crystallization time also depends on temperature of the wall rock. Figure 13 shows the time for crystallization and cooling of multiple dikes periodically intruding at a 6-month interval with the initial wallrock temperatures of $0^{\circ}, 250^{\circ}$, and $500^{\circ} \mathrm{C}$. The crystallization time for the first dike with the initial wall-rock temperature of $0^{\circ}$ and $250^{\circ}$ is 120 and $160 \mathrm{hr}$ respectively, but it increases only $400 \%$ and $580 \%$ 


\section{A}

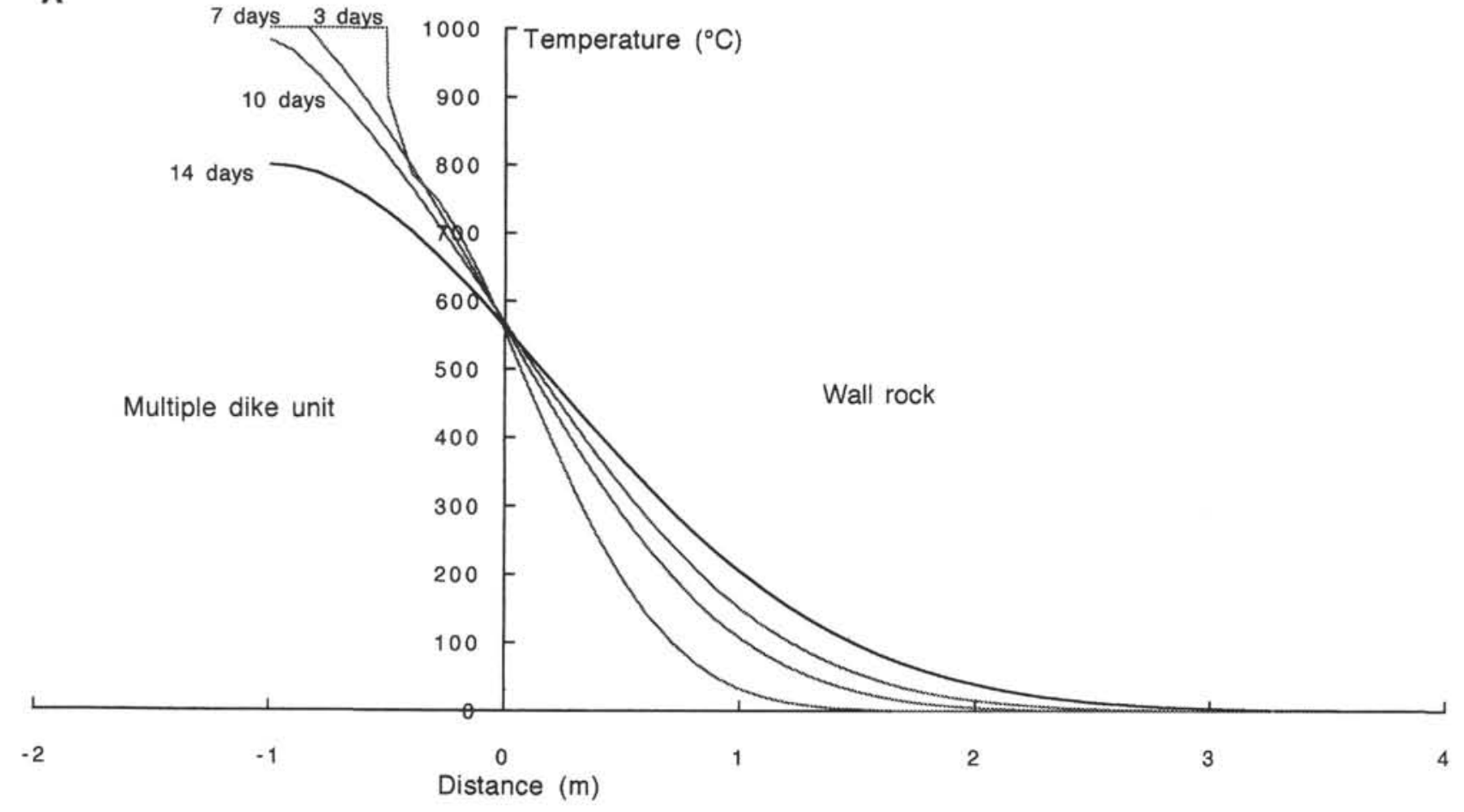

Figure 10. Solidification of a multiple dike with each expansion of $1 \mathrm{~m}$. New injection occurs when the center of the multiple dike cools $800^{\circ} \mathrm{C}$. Variation of temperature profiles is shown from the center of the multiple dike through the host rock. Temperature profiles in the second (A) and third dikes (B) are shown.

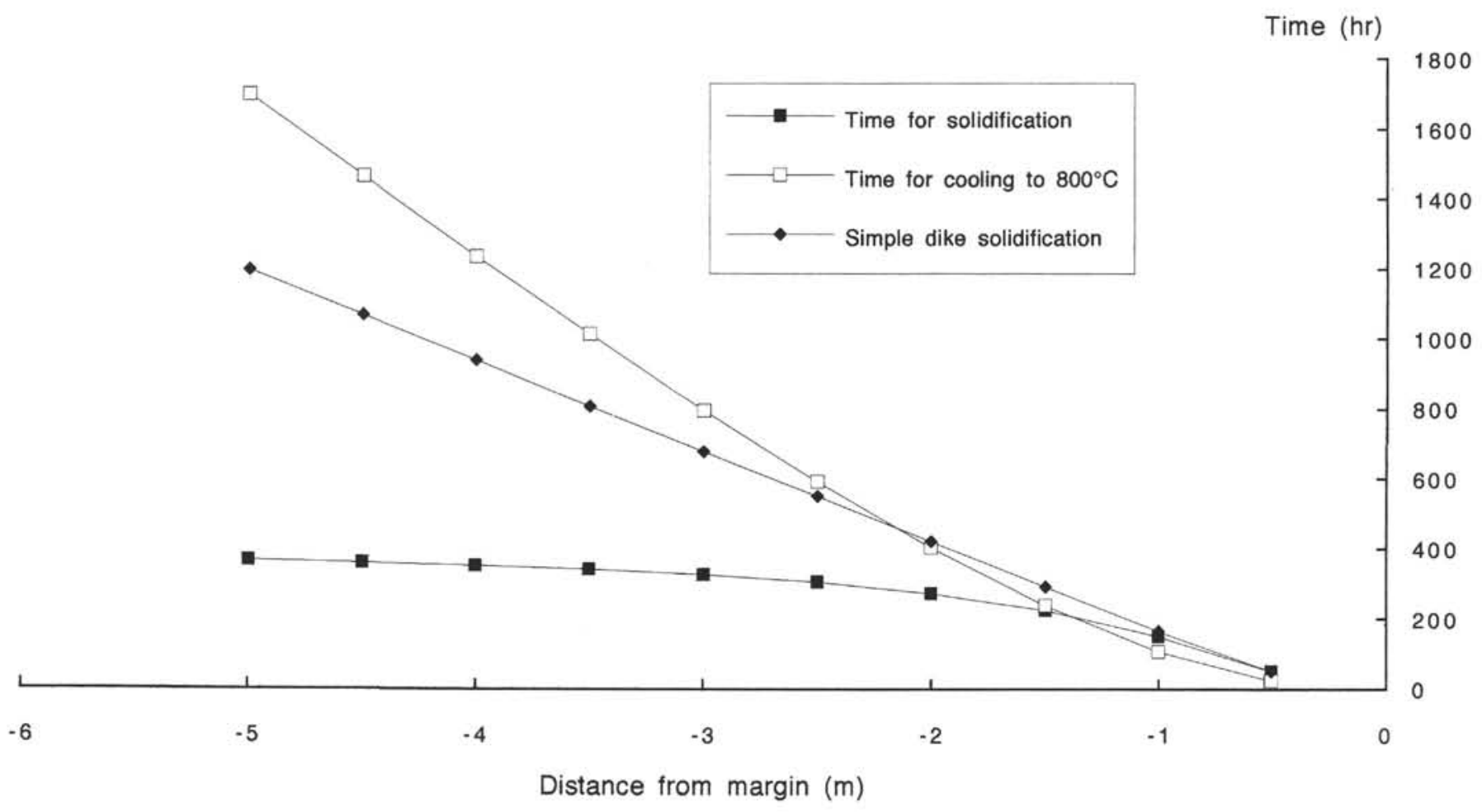

Figure 11. Time required for solidification and cooling of a multiple dike with 1-m-thick injections. The multiple intrusion occurs when the center of the multiple dike cools to $800^{\circ} \mathrm{C}$. Time required for solidification or cooling of every $0.5 \mathrm{~m}$ of a simple dike is also shown for comparison. 
B

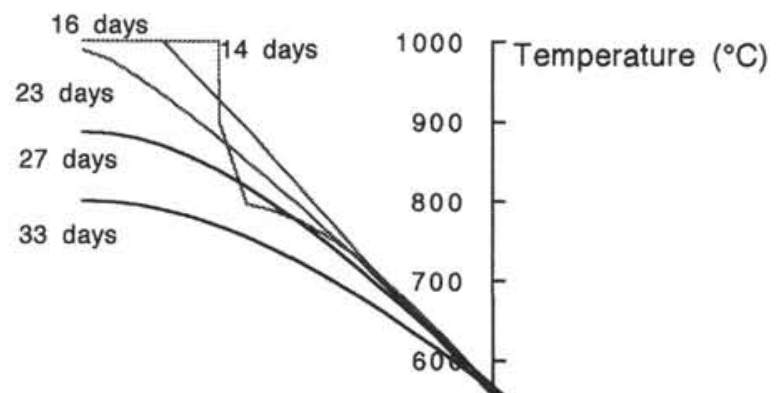

Multiple dike unit
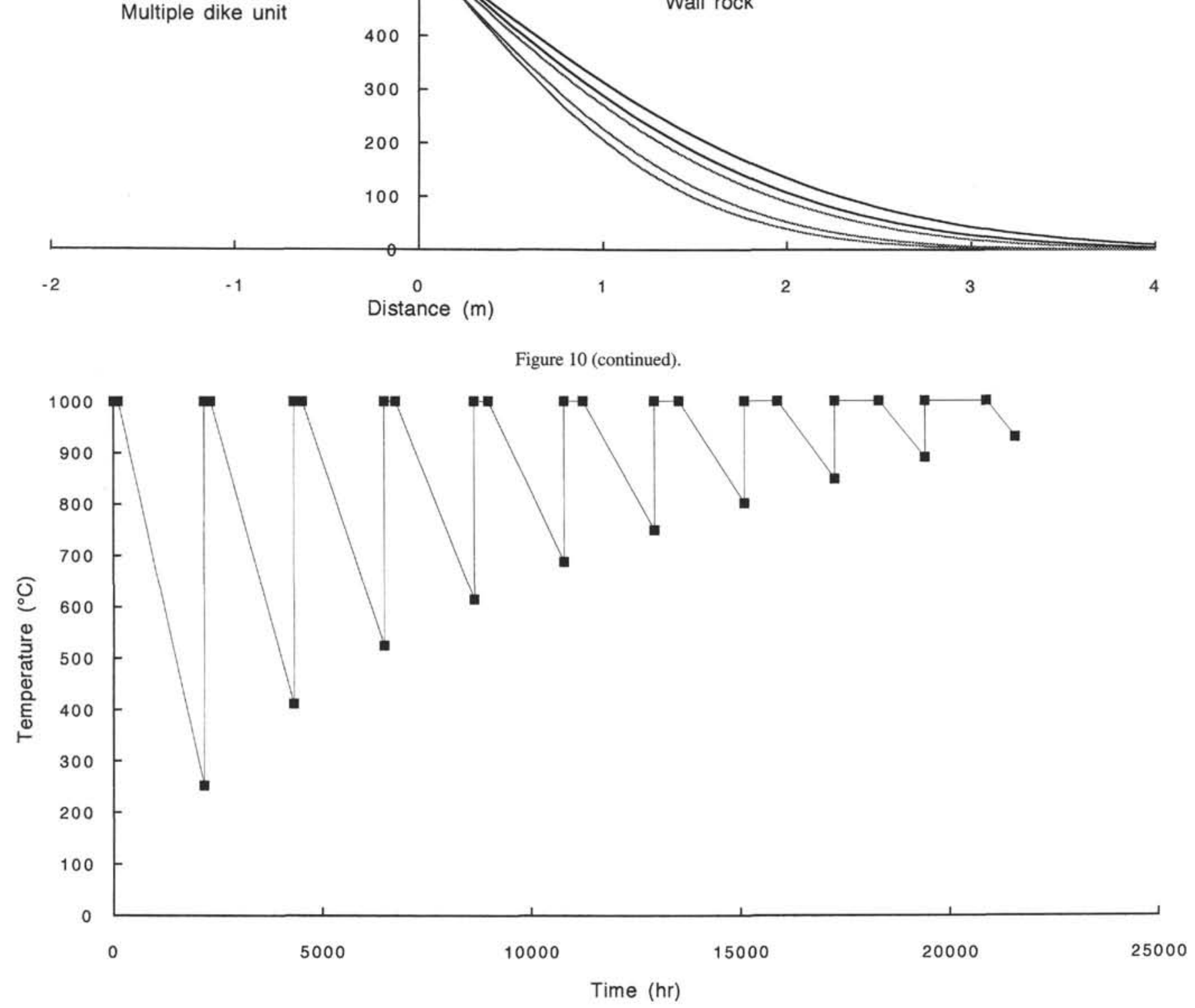

Figure 12. Variation in temperature at the center of a multiple dike intruding every 3 months at initial wall-rock temperature of $0^{\circ} \mathrm{C}$. As the intrusion is repeated, the temperature of the center of the multiple dike steadily increases.

after nine repetitions of the intrusion. That for the first dike with the initial wall-rock temperature of $500^{\circ} \mathrm{C}$ is $257 \mathrm{hr}$, while it largely increases more than twice for the fourth dike, and up to 12 times for the tenth dike. Thus, both the decrease in the intrusive time interval and the increase in the initial wall-rock temperature largely increases the crystallization time of the multiple dike units.

\section{Relationships Between Crystallization Time and Grain Size}

Relationships between the grain size and the crystallization time depend on the nucleation and growth rate, which are functions of temperature, pressure, and chemical composition of the magma, and also 
Time (days)

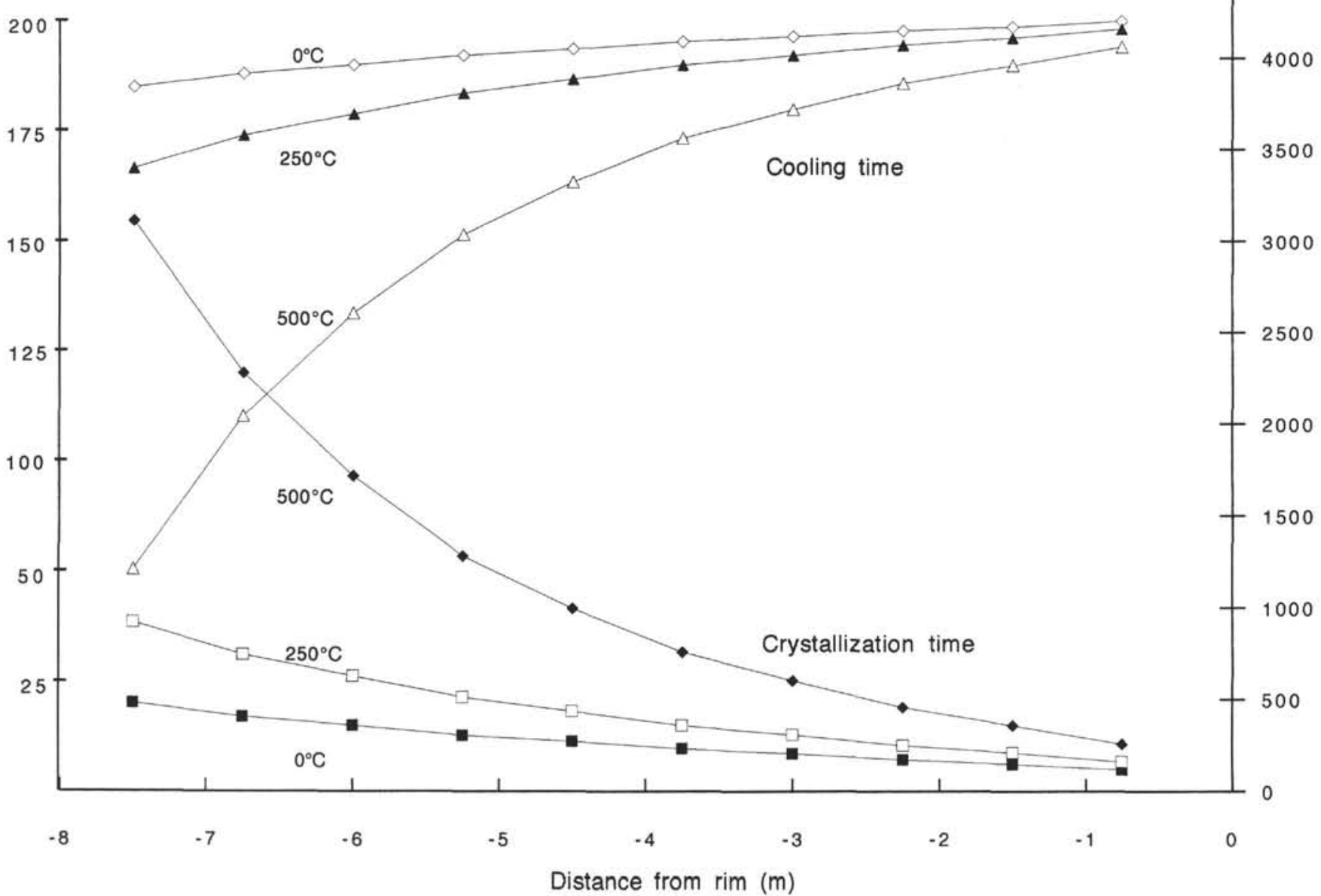

Figure 13. Time for crystallization (lower three curves) and cooling between dike injections (upper three curves) of multiple dikes. An individual dike has the width of $1.5 \mathrm{~m}$ and is emplaced every 6 months at initial wall-rock temperatures of $0^{\circ} \mathrm{C}, 250^{\circ} \mathrm{C}$, and $500^{\circ} \mathrm{C}$. Symbols connected with a line represent injection of the first, second, third, etc., dikes from the right.

on physical properties of the magma and the wall rock, such as thermal conductivity, thermal diffusivity, heat capacity, and latent heat of crystallization. Numerical simulations of crystallization of a dike of a hypothetical binary magma have been presented by Spohn et al. (1988). They showed that (1) logarithm of grain size is linearly correlated with the wall-rock temperature, and (2) the difference in square root of the crystallization time is correlated with the wall-rock temperatures:

$$
\begin{gathered}
\log \rho_{m}=0.44 \theta-1.19 \\
\frac{\Delta \sqrt{\tau_{c}}}{\Delta \theta_{R}}=7.11 \theta
\end{gathered}
$$

(when $A v=2 \times 10^{5}$ ) where $\rho_{m}$ is non-dimensional crystal size, $\tau \mathrm{c}$ is the crystallization time, $\theta_{R}$ is the initial wall rock temperature, and Av is Avrami number defined as

$$
A v=\sigma I U^{3} /\left(D^{2} / \kappa\right)^{4},
$$

$(\sigma$ : Shape factor) which is a function of nucleation $(I)$ and growth $(U)$ rates, width of the dike $(D)$, and thermal diffusivity $(\kappa)$. By combining Equations 1 and 2, we get

$$
\begin{aligned}
& \sqrt{\tau_{c}}=C \log \rho_{m}+D \\
& \Delta \sqrt{\tau_{c}}=C \Delta \log \rho_{m}
\end{aligned}
$$

(C, D: constant).
Thus, the difference in square root of the crystallization time is linearly correlated with the difference in logarithmic grain size. Figure 14 shows relationships between the crystallization time for basaltic andesite dikes from Iritono, Northeast Japan (Ikeda, 1977), and Makaopuhi lava lake, Hawaii (Kirkpatrick, 1977), together with the best fit lines. Except for the smallest two data points from the Iritono dikes, both Iritono and Makaopuhi data sets show crude linear relationships with similar inclinations. The inclination depends on the system, such as composition of the magma, phase relations, and physical properties of the magma and the wall rock. The Iritono dikes are basaltic andesite that intruded into granitic plutons at depth, while the Makaopuhi lava lake is basalt ponded on the East Rift Zone of Kilauea. Although these two largely differ in conditions for crystallization, both show similar inclinations. Therefore, we may assume a similar inclination for the Hole 504B dikes so that we can correlate variations in the grain size directly with those in the crystallization time.

Figure 15 shows variations in maximum plagioclase length relative to that of the outermost dike plotted against distance from the margin of the multiple dike units. Also plotted on the diagram are estimated relative grain sizes of multiple dikes, each with an expansion of $1.5-\mathrm{m}$ width and a time interval of 6 and 3 months, using Equation 4. Cooling Units 5 and 10 are plotted around the data points of a 3-month interval and with the initial host rock temperature of $0^{\circ} \mathrm{C}$, and those of a 6-month interval and $0^{\circ} \mathrm{C}$ host rock temperature. The first three points of cooling Unit 1 are plotted higher than the 6 -month, $500^{\circ} \mathrm{C}$ variation curve, but the outer three points (second, 


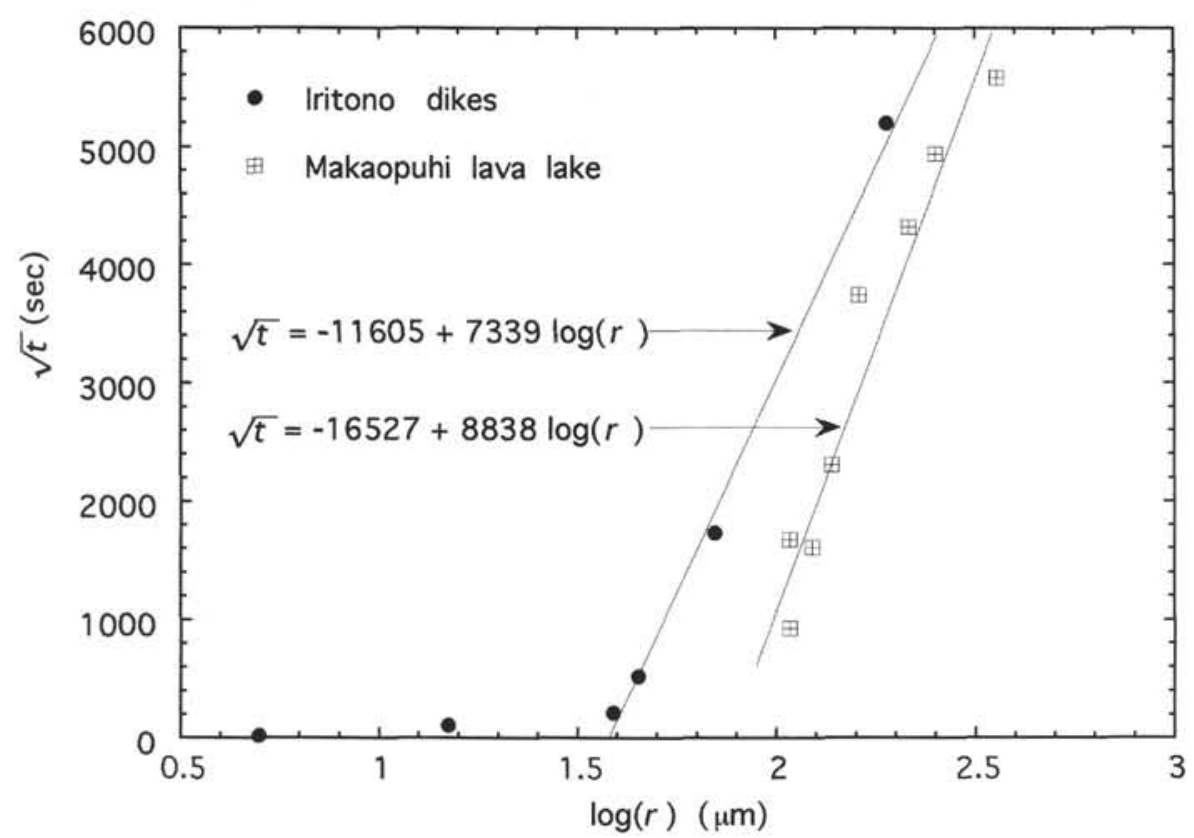

Figure 14. Square root of crystallization time plotted against logarithm of plagioclase size in Iritono dikes, northeast Japan, and in Makaopuhi lava lake, Hawaii. Data points show linear relationships between square root of time and logarithm of size, although two data points of Iritono for smaller size do not fit the line.

third, and fourth dikes) are close to the curve. If the initial wall-rock temperature was higher than $500^{\circ} \mathrm{C}$, the outer dikes in the cooling Unit 1 would be much coarser. This is probably because the first data of cooling unit 1 is not the coarsest sample in the first dike but was taken from near the fine-grained margin, or the first four dikes intruded successively in a short period.

Natural multiple dike units are composed of dikes with various width emplaced at uneven time intervals. Figure 16 shows a relative variation in maximum plagioclase length of the cooling Unit 5. Also shown are calculated grain-size variations for injection at 6-month intervals and $0^{\circ} \mathrm{C}$ initial wall-rock temperature and for 3-month intervals at $250^{\circ} \mathrm{C}$. In both calculations, the widths of dikes are adjusted to the real dike width. Both lines for 3- and 6-month intervals are plotted slightly above or below the natural data points, but do not fit well. This is undoubtedly due to variations in the time interval of the dike emplacement. The best fit solution for cooling Unit 5 is also shown in Figure 16. The second dike intrudes 39 days after the emplacement of the first dike, and the third dike intrudes 56 days after the second one. The fourth and fifth injection of dike occurred 7 months later and further 6 months later.

Because of uncertainties arising from sampling, even the best fit solutions for the natural cooling units do not reproduce the precise time intervals and the initial wall-rock temperatures when the multiple dike intrusions took place, but give the most plausible estimates of these variables; individual dikes of the multiple dike units would have been emplaced at intervals of 1-7 months and initial wall rock temperature of $0^{\circ}-250^{\circ} \mathrm{C}$, which are comparable to the dike intrusions observed in Krafla and Kilauea (Tryggvason, 1984; Yang et al., 1992).

\section{RIFTING EPISODES AT DIVERGENT PLATE BOUNDARIES}

The downhole grain-size variation shows monotonous increases or decreases segmented by occasional jumps. It does not show any symmetrical grain size variations expected for those through the whole section of a single dike or a multiple dike unit, and hence complete sections through single dikes or multiple dike units are scarcely seen in the drill hole. Therefore, the width of an individual cooling unit gives the minimum of half of the width of a correspond- ing multiple dike unit. The average width of the 16 cooling units below $1570 \mathrm{mbsf}$ is $5.13 \mathrm{~m}$ for the minimum dip of $79^{\circ}$ and $2.81 \mathrm{~m}$ for the maximum dip of $84^{\circ}$, and $3.98 \mathrm{~m}$ for the average dip of $81.5^{\circ}$. Although there is no direct observation of volcanic eruptions and tectonic movements in mid-ocean spreading axes, it is plausible that rifting in oceanic ridges is also an episodic event associated with successive intrusion of dikes in a short period which forms a multiple dike unit and that individual rifting events are intercalated with comparatively long quiescent periods. Thus, each cooling unit represents a minimum amount of crustal extension through individual rifting episodes. The average maximum expansion of the rifting would be at least twice as much as the average width of the cooling units, ranging from 5.6 to $10.3 \mathrm{~m}$ and $8.0 \mathrm{~m}$ on the average. As the full spreading rate of the Costa Rica Rift is $7.2 \mathrm{~cm} / \mathrm{yr}$, the time interval of rifting would have been $114 \pm 33 \mathrm{yr}$. As deduced from the grain-size variations, each rifting episode forms a multiple dike unit through intermittent dike intrusions repeated at 1- to 12-month intervals and lasting for at least $2-3 \mathrm{yr}$.

Historical records of major fissure eruptions and tectonism in Iceland are thought to be manifestations of such rifting events. These include fissuring and eruptions of the Krafla swarm in 1724-1729 and in 1975-1981, fissure eruption of Suveinagja and Askja caldera in 1874-1875, and the great Laki eruption and volcanic activity in Grímsvötn central volcano in 1783. Each rifting event lasted 1-6 yr during which intermittent dike intrusions and fissuring took place (Sigurdsson and Sparks, 1978 ). During the latest spreading episode in the Krafla system, a number of dike intrusions were inferred by rapid deflations in the caldera area and earthquakes along the fissure swarm, each of which lasted for only several hours and were separated by long quiescent periods of $2-10$ months. The expansion at a single intrusion was $0.5-3 \mathrm{~m}$ and the total widening was $3.5 \mathrm{~m}$ on the average for the whole $80-\mathrm{km}$-long fissure swarm. These time intervals between dike intrusions and the duration of the rifting episode are comparable to those at the Hole 504B dike swarm.

If spreading episodes in Iceland occur every $100-150 \mathrm{yr}$, the full spreading rate of $1.9 \mathrm{~cm} / \mathrm{yr}$ gives an average expansion of $1.9-2.9 \mathrm{~m}$ during a single rifting. The $3.5-\mathrm{m}$ expansion of the Krafla event is $84 \%-21 \%$ higher than the expected widening by the NUVEL plate velocity model. At divergent plate boundaries the crust is approxi- 


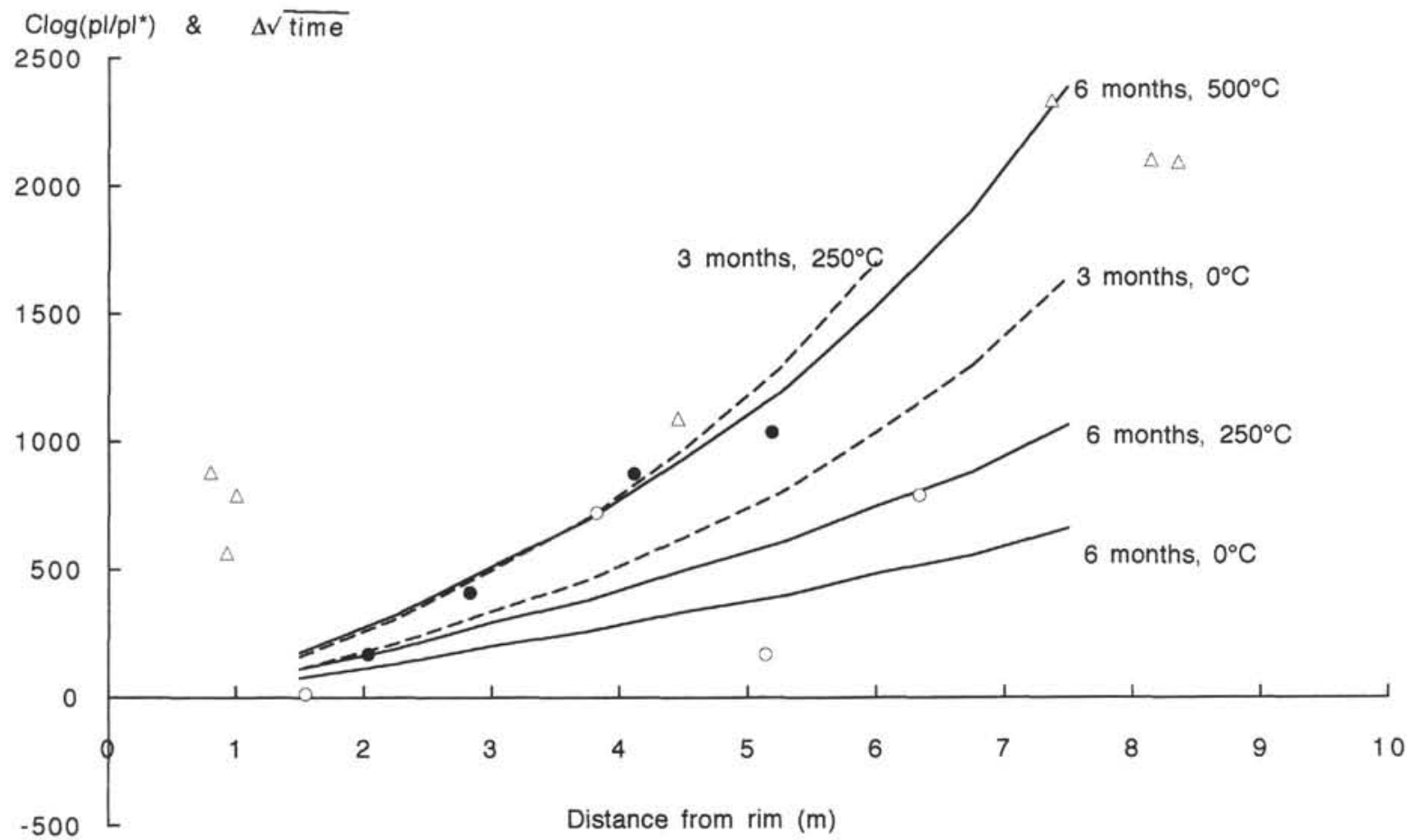

Figure 15. Variations in relative length of plagioclase with distance from the margin of cooling Units 1 (open triangles), 5 (solid circles), and 10 (open circles). Curves are simulated plagioclase length variations for multiple intrusions with 1.5 -m-wide dikes injected every 3 and 6 months at initial wall-rock temperatures of $0^{\circ} \mathrm{C}, 250^{\circ} \mathrm{C}$, and $500^{\circ} \mathrm{C}$.

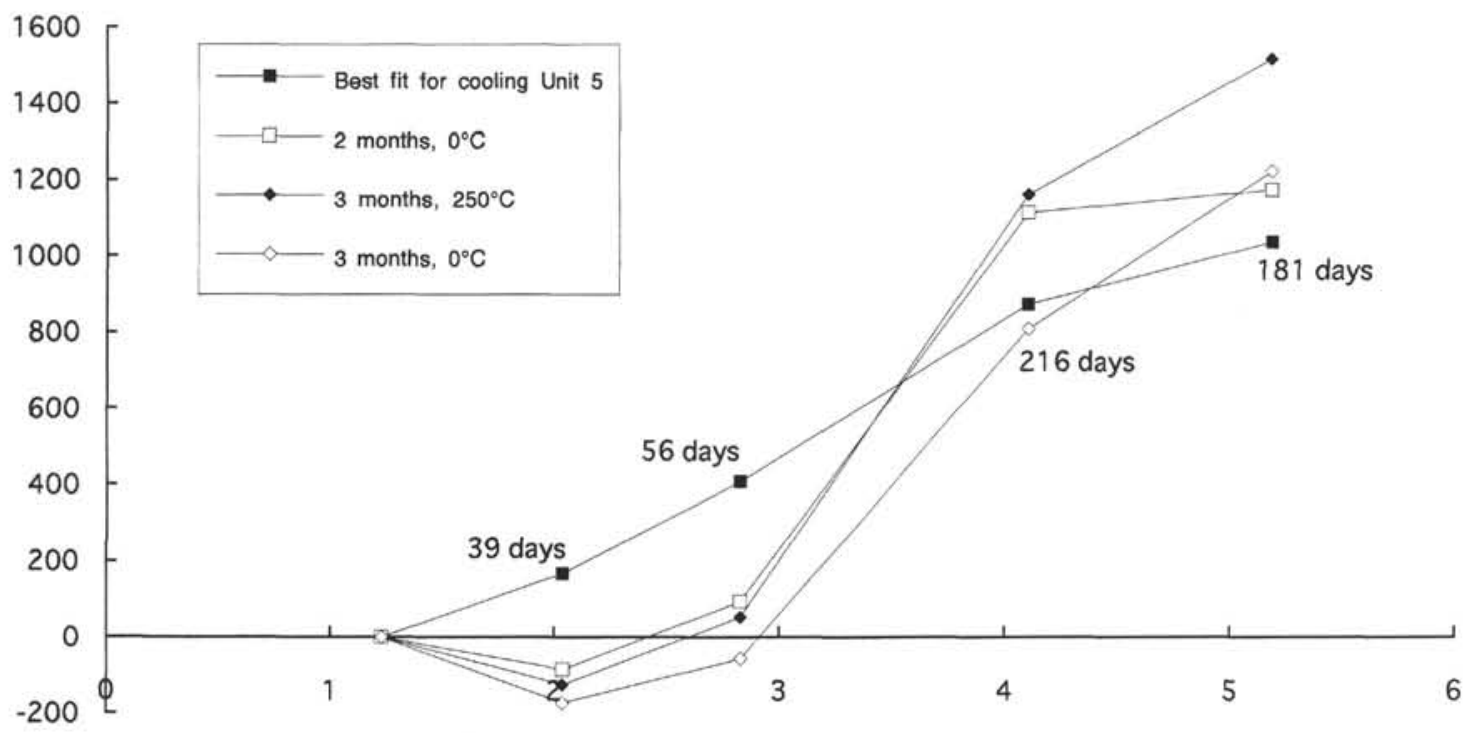

Figure 16. Variation in relative plagioclase length of cooling Unit 5 compared with simulations. Three lines plotted below or above cooling Unit 5 are calculated variations for dikes with the same width as Unit 5 but emplaced at constant intervals of 2 and 3 months in host rocks with initial temperature of $0^{\circ} \mathrm{C}$ and $250^{\circ} \mathrm{C}$. The best fit solution indicates that the second dike of cooling Unit 5 was emplaced 39 days after the intrusion of the first dike. The third, fourth, and fifth dikes intruded at intervals of 56,216 , and 181 days, respectively.

mated by a brittle plate underlain by the molten asthenosphere and a magma chamber. Then, the frequency of dike intrusions is given by

$$
I f=E v / \sigma u,(\text { Gudmundsson, 1990) }
$$

where $E$ is Young's modulus, $v$ is full spreading rate, $\sigma$ is tensile stress and $u$ is the width of a volcanic zone under stress. Gudmundsson (1988) estimates the static Young's modulus at the bottom of the crust in Iceland to be $51 \mathrm{GPa}$ and the tensile strength to be $3 \mathrm{MPa}$. The neovolcanic zone in northeastern Iceland is $45-80 \mathrm{~km}$ in width and comprises four partly overlapping fissure swarms aligned en echelon. Thus, the width of one fissure swarm is approximately $10 \mathrm{~km}$, and the average spreading rate per each is $0.5 \mathrm{~cm} / \mathrm{yr}$. By substituting $E=51$ $\mathrm{GPa}, v=0.5 \mathrm{~cm} / \mathrm{yr}, \sigma=3 \mathrm{MPa}$, and $u=10 \mathrm{~km}$, Gudmundsson (1990) obtained the dike injection frequency in Iceland $(I f)$ to be $0.0085 / \mathrm{yr}$, that is, one dike injection every $118 \mathrm{yr}$, which is within the range of 
the rifting episode deduced from historical records. Although we do not know the exact area of recent fissuring at the Costa Rica Rift, the inner valley floor would be the most plausible location. The spreading center is indicated by inward-facing steep scarps about $50 \mathrm{~km}$ apart on top and a 700 -m-deep valley. The valley floor is approximately 20 $\mathrm{km}$ wide, which would be subjected to recent intense fissuring and dike intrusions. Young's modulus for the crustal layers of the Semail ophiolite is $67 \mathrm{GPa}$ (Gudmundsson, 1990). If Young's modulus is 51-67 GPa and the tensile strength at the roof of the subcrustal magma chamber is $3 \mathrm{MPa}$, the time interval of the spreading episode at Costa Rica Rift is $12-16$ yr. This value is only $8 \%-20 \%$ of that estimated from the multiple dike units. This discrepancy partly comes from an overestimation of the width of the multiple dike units. Because of poor recovery of the cores and still rare recovery of the contact between two lithologic units (dikes), misidentification of a multiple dike unit may arise when it intrudes into the host rock consisting of fine-grained old dikes. Then the fine-grained host may be mistaken for part of the multiple dike unit and hence the width of the whole unit is overestimated. The other possibility is that the number of dikes decreases upward and the width of dikes tends to increase and becomes shorter upward (Gudmundsson, 1990). This is because the length-to-width ratio of a dike and the intrusion frequency are proportional to Young's modulus, which is higher in the deeper part of the crust.

Geodetic measurements such as very long baseline interferometry (VLBI) have detected relative plate movements in only a year-long observation, which is consistent with the average rates of the plate motion determined by the stripes of magnetic anomalies (Heki et al., 1987). If the rifting at spreading ridges is an episodic event occurring every $10-100 \mathrm{yr}$, the crustal movements during a rifting episode must differ from large-scale plate movements. The last expansion of the Krafla fissure swarm was 18 November 1981, and no fissuring and dike intrusion have occurred since then. Recently, geodetic measurements using the global positioning system (GPS) were conducted in 1987 and 1990 in the Krafla system (Foulger et al., 1992). The GPS measurement showed the maximum extension up to $15 \mathrm{~cm}$, which is three times larger than that expected from the full spreading rate in Iceland. Foulger et al. (1992) have explained it as stress relaxation of the crust adjacent to the fissure swarm. Because dike intrusions expand the crust in a short period, the strain rate is so high that the crust adjacent to the fissures cannot catch up with the deformation and are strongly compressed. Then, relaxation of stress occurs during a long period after the intrusions and the deformation diffuses to the surrounding crust. A numerical simulation of such a diffusive stress relaxation show that repeated expansions of 5-6 m at intervals of 100 yr would be observed as a continuous crustal movement at a rate of $1-2 \mathrm{~cm} / \mathrm{yr}$ at distances beyond $100 \mathrm{~km}$, and could well explain the average spreading rate at Iceland (Heki et al., 1993).

Thus, the regional crustal movements are time-integrated, averaged diffusion processes of deformation, intermittently taking place along plate boundaries such as ridge systems and trenches. In contrast, spreading at diverging plate boundaries is an episodic expansion of the fissure swarm lasting for only several years, which is separated by quiescent periods of 10 to several hundred years.

\section{ACKNOWLEDGMENTS}

I thank all the shipboard scientists, technicians, and crew, especially those who decided to make dense sampling and many thin sections, which made all this work possible. Careful and fine reviews by Katharine V. Cashman, Bruce D. Marsh, and Henry J.B. Dick are gratefully acknowledged.

\section{REFERENCES}

Adamson, A.C., 1985. Basement lithostratigraphy, Deep Sea Drilling Project Hole 504B. In Anderson, R.N., Honnorez, J., Becker, K., et al., Init. Repts. DSDP, 83: Washington (U.S. Govt. Printing Office), 121-127.
Baragar, W.R.A., Lambert, M.B., Baglow, N., and Gibson, I.L, 1990. The sheeted dyke zone in the Troodos Ophiolite. In Malpas, J., Moores, E.M., Panayiotou, A., Xenophontos, C. (Eds.), Ophiolites: Oceanic Crustal Analogues. Cyprus Geol. Surv. Dep., Min. Agr. Nat., Res., 37-51.

Becker, K., Sakai, H., et al., 1988. Proc. ODP, Init. Repts., 111: College Station, TX (Ocean Drilling Program).

Cashman, K.V., 1990. Textural constraints on the kinetics of crystallization of igneous rocks. In Nicholls, J., and Russell, J.K. (Eds.), Modern Methods of Igneous Petrology: Understanding Magmatic Processes. Mineral. Soc. Am., 259-314.

Cashman, K.V., and Marsh, B.D., 1988. Crystal size distribution (CSD) in rocks and the kinetics and dynamics of crystallization, II: Makaopuhi lava lake. Contrib. Mineral. Petrol., 99:292-305.

Foulger, G.R., Jahn, C.-H., Seeber, G., Einarsson, P., Julian, B.R., and Heki, K., 1992. Post-rifting stress relaxation at the divergent plate boundary in Northeast Iceland. Nature, 358:488-490.

Gautneb, H., and Gudmundsson, A., 1992. Effect of local and regional stress fields on sheet emplacement in West Iceland. J. Volcanol. Geotherm. Res., $51: 339-356$

Gudmundsson, A., 1988. Effect of tensile stress concentration around magma chambers on intrusion and extrusion frequencies. J. Volcanol. Geotherm. Res., 35:179-194.

, 1990. Dyke emplacement at divergent plate boundaries. In Parker, A.J., et al. (Eds.), Mafic Dykes and Emplacement Mechanisms. Proc. 2nd Int. Dyke Conf. Adelaide, South Australia, 47-62.

Heki, K., Foulger, G.R., Julian, B.R., and Jahn, C.-H., 1993. Plate dynamics near divergent boundaries: geophysical implications of postrifting crustal deformation in NE Iceland. J. Geophys. Res., 98:14279-14297.

Heki, K., Takahashi, Y., Kondo, T., Kawaguchi, N., Takahashi, F., and Kawano, N., 1987. The relative movement of the North American and Pacific plates in 1984-1985, detected by the Pacific VLBI network. Tectonophysics, 144:151-158.

Ikeda, Y., 1977. Grain size of plagioclase of the basaltic andesite dikes, Iritono, central Abukuma Plateau. Can. J. Earth Sci., 14:1860-1866.

Kirkpatrick, R.J., 1977. Nucleation and growth of plagioclase, Makaopuhi and Alae lava lakes, Kilauea Volcano, Hawaii. Geol. Soc. Am. Bull., 88:78-84.

Kong, L.S.L., Detrick, R.S., Fox, P.J., Mayer, L.A., and Ryan, W.F.B., 1989. The morphology and tectonics of the MARK area from Sea Beam and MARC 1 observations (Mid-Atlantic Ridge $23^{\circ} \mathrm{N}$ ). Mar. Geophys. Res., 10:59-90.

Marsh, B.D., 1988. Crystal size distribution (CSD) in rocks and the kinetics and dynamics of crystallization, I: Theory. Contrib. Mineral. Petrol., 99:277-291.

Shipboard Scientific Party, 1992. Site 504. In Dick, H.J.B., Erzinger, J., Stokking, L.B., et al., Proc. ODP, Init. Repts., 140: College Station, TX (Ocean Drilling Program), 37-200.

Sigurdsson, H., and Sparks, R.S.J., 1978. Lateral magma flow within rifted Icelandic crust. Nature, 274:126-130.

Smith, D.K., and Cann, J.R., 1992. The role of seamount volcanism in crustal construction at the Mid-Atlantic Ridge $\left(24^{\circ}-30^{\circ} \mathrm{N}\right)$. J. Geophys. Res. 97:1645-1658.

Spohn, T., Hort, M., and Fischer, H., 1988. Numerical simulation of the crystallization of multicomponent melts in thin dikes or sills, 1 : the liquidus phase. J. Geophys. Res., 93:4880-4894.

Tryggvason, E., 1984. Widening of the Krafla fissure swarm during the 1975-1981 volcano-tectonic episode. Bull. Volcanol., 47:47-69.

Turcotte, D.L., and Schubert, G., 1982. Geodynamics: Applications of Continuum Physics to Geological Problems: New York (Wiley).

Yang, X., Davis, P.M., Delaney, P.T., and Okamura, A.T., 1992. Geodetic analysis of dike intrusion and motion of the magma reservoir beneath the summit of Kilauea Volcano, Hawaii: 1970-1985. J. Geophys. Res., 97:3305-3324.

\footnotetext{
Abbreviations for names of organizations and publications in ODP reference lists follow the style given in Chemical Abstracts Service Source Index (published by American Chemical Society).
}

Date of initial receipt: 24 February 1994

Date of acceptance: 5 July 1994

Ms 137/140SR-002 